\title{
Moderating Effect of Capital Outflow Monitoring Management (COMM) on Credit Risk and Loan Performance
}

\author{
Muhammad Irfai Sohilauw ${ }^{1}$, Muhammad Ali $^{2}$ and Mursalim Nohong ${ }^{3}$ \\ ${ }^{1}$ Hasanuddin University, Indonesia, e-mail: Sohilauw1899@gmail.com \\ ${ }^{2}$ Hasanuddin University, Indonesia \\ ${ }^{3}$ Hasanuddin University, Indonesia
}

\begin{abstract}
This study aims to explain the relationship between credit risk and loan performance which is moderated by Capital outflow monitoring management (COMM). This research is an explanatory research in the city of Makassar. The population in this study is the Associate Account Officer (AAO) of the Makassar BRI Regional Office in 2009. The selection of research samples using NonProbability Sampling with saturated sampling method. Data were analyzed using descriptive and inferential statistical methods. By using the help of Smart PLS 3.0 software, the results of the study indicate that Capital Outflow monitoring management (COMM) does not affect the relationship of Credit risk to loan performance.

Keywords: Credit Risk; Loan Performance; Business Mentoring; Customer relationship management; Account Officer
\end{abstract}

\section{Introduction}

The concept of intermediation is that banks become intermediaries from parties who have excessive funds (surplus) and then channeled to those who lack funds (deficit) (investopedia.com, 2010). Therefore, banks must be able to mobilize public funds appropriately and quickly in channeling funds for effective and efficient use or investment. In its role as a lender, banks must assess the creditworthiness of new borrowers, just as they must monitor regularly whether the debtor will repay their loans (L. Nguyen, 2016)

Credit is one of the bank's services as an embodiment of the intermediary function. In addition, credit is the main banking service because it is the largest source of income among other banking services (Klein, 1971), plays an important role in monetary policy (Morris \& Sellon, 1995), and which aims to maximize corporate profits (Lalon, 2015). The bank will lose if the debtor's rate of return is low and has the potential to increase credit risk, which is the main risk faced by the bank. (Grinis, 2015); (Klieštik \& Cúg, 2015). Thus, the Bank is required to reserve losses to cover the debtor's defaults (Svitek, 2011); (Balla \& Rose, 2011). Non-performing loans generally refer to loans that do not generate income for a relatively long period of time; namely the principal and / or interest on this loan is not paid for at least 90 days (Akinlo \& Emmanuel, 2014). Credit risk will arise from debtors who do not pay credit installments or their financial capacity deteriorates and results in economic losses for banks (Spuchl'áková, Valašková, \& Adamko, 2015). Therefore, risk mitigation can be done by implementing a good credit risk management system by the lenders to reduce the likelihood of failure to repay credit installments, or in other words maintain the quality of loans from non-performing loans (Zaini Abd Karim, Chan, \& Hassan, 2010). In fact, failure to pay installments (by debtors) will result in a decrease in bank income (Pottow, Lawless, Littwin, Porter., \& Thorne, 2008), and the risk will be borne by each financial institution (Gweyi, 2013). At this stage, the ability of credit officers (in this case account officer / AO) is absolutely necessary as an extension of the bank's hand with debtors or prospective borrowers

The ability of credit executors is very important in a bank's credit system. Marketing (account officer) is at the forefront as the spearhead of executing credit from financial institutions to process credit (analysis, monitoring, coaching and collection). Therefore, AO is required to have good skills and knowledge about credit and things that support the credit process (Baklouti \& Baccar, 2013). As an 
extension of the bank, $\mathrm{AO}$ is expected to gather information about the financing process, both from the debtor and from other parties related to the credit process (Wachira, 2017). AO must have knowledge in the credit assessment process (Njeru, Mohammed, \& Wachira, 2016); (Kiplimo \& Kalio, 2014); (Ahmed \& Malik, 2015); (Thisika \& Jomo, 2017); have the ability to monitor loans (Murigi \& Thuo, 2018); (Lagat, Mugo, \& Otuya, 2013); (Kimotho \& Gekara, 2016); (Kalu, Shieler, \& Amu, 2018); (Gustafson, Ivanov, \& Meisenzahl, 2016); and has the ability to collect credit installments (Moti, Masinde, Mugenda, \& Sindani, 2012). All of these skills are needed to control credit risk that might occur (Maina, Kinyariro, \& Harrison, 2016); (Kimotho \& Gekara, 2016) because it will affect loan performance and is directly proportional to the bank's profitability. In relation to credit risk management, $\mathrm{AO}$ must be professional in carrying out its duties. AO must rigorously select every incoming proposal, so it is expected that the credit decision will be right on target. In addition, $\mathrm{AO}$ is obliged to be responsible during the financing period, due to the biggest weakness in the financing process according to DeYoung (2017), L. Nguyen (2016), Spuchl'áková et al. (2015) and Abor (2007) are the stages of monitoring and maintenance of debtors. Wachira (2017) found that the majority of banks will check and supervise loans after being disbursed. Kalu et al. (2018); Lagat et al. (2013) also found that the process of monitoring and mitigating credit risk has a positive relationship with financial performance. Maina et al. (2016) revealed that there is a strong relationship between credit risk monitoring, billing policy and loan arrears. Kimotho \& Gekara (2016); Alshatti (2015); Kibor, Ngahu, \& Kwasira (2015)recommend that the need for supervision, standardization and policies in the credit process, because it is very influential on bank profitability. However, Kithinji (2010); Ruziqa (2013); Embaye, Zahara, \& Abderaman (2017) found that bank profitability is not affected by credit risk management. Then Lebbe, Rauf, \& Mulafara (2016); Otieno, Nyagol, \& Onditi (2016) found that credit risk management did not significantly affect the credit performance of commercial banks. Dan Maluni (2011) concludes that the level of problem loans is inversely proportional to credit risk management practices.

In this study, the problem raised was "how to build a conceptual model and empirical research model to overcome the gap between credit risk and bank loan performance in the city of Makassar?".

This research will try to describe the gap between credit risk and loan performance through the moderation of capital outflow monitoring management (COMM). In connection with the research problems that have been described, the research questions compiled are as follows :

1. Is there an effect of credit risk $(\mathrm{X})$ on loan performance $(\mathrm{Y})$ ?

2. Is there an effect of credit risk (X) on loan performance $(\mathrm{Y})$ through the moderation of Capital Outflow monitoring management (COMM) $(\mathrm{Z})$ ?

The purpose of this study is to develop a conceptual model that illustrates and empirically demonstrates how credit risk and Capital Outflow monitoring management (COMM) are well managed to increase loan performance in the city of Makassar;

Resource Based View Theory. Resources are things that are considered as strengths or even weaknesses of a company, consisting of tangible and intangible assets. Intangible resources include financial capital (equity, debt, retained earnings) and physical capital (machinery and buildings). Intangible resources consist of entrepreneurial knowledge, skills, experience, standard operating procedures (SOP) and organizational reputation (Eniola \& Entebang, 2015). The main idea of the $\mathrm{RBV}$ is that companies will achieve competitive advantage, be sustainable, grow and have more performance if they are able to own and control resources with capabilities that are valuable, rare, incomparable and irreplaceable, provided they have the ability to absorb and accommodate them (Barney, 1991). For example, resources that can produce sustainable competitive advantages that include assets, capabilities, organizational processes, information and knowledge. The collection of resources available to the company is very important to produce competitive advantages, and can be used to carry out various company activities.

Srinivasan \& Fox (1993) argue that a company's ability to manage relationships with creditors is a major source of competitive advantage. Thus, human resources (experience and capabilities, trust, 
managerial skills, top management practices and procedures, middle management, administration and production) can also explain the level of competitive advantage of the company and the performance of the company produced. Barney \& Hesterly (2015) states that human resources also include training, knowledge, experience, assessment, intelligence, attitudes, relationships, and manager's insight in the company. Evidence of previous empirical studies of organizational learning and entrepreneurship suggests investment decision making is based on experiential learning, not formal methods.

In relation to credit risk management, the lender (in this case the account officer) must be truly professional in carrying out his duties. AO must carefully select every incoming proposal, so that the credit decision will be expected to be appropriate because it is in accordance with the applicable regulations. In addition, AO is obliged to be responsible during the financing period, because the biggest weakness in the financing process according to DeYoung (2017) is the stage of monitoring and maintenance of debtors. $\mathrm{AO}$ is also expected to maximize the process to obtain information related to the debtor's credit, so that it can be a guide for strategic decision making and also as an early warning system.

Account Officer. One of the factors that determines the smoothness of bank business is its success in managing bank liquidity (Bagh, Razzaq, Azad, Liaqat, \& Khan, 2017). This will not be achieved if the customer who has been financed is unable to repay his obligation. For this reason, Account Officers as bank employees who make credit proposals must be observant and thorough in choosing competent customers so that the risk of bad credit can be minimized (Osei-Nyarko, 2015)

Since the banking deregulation was launched by the government, especially since the pakto (October policy package) 27 , the Indonesian banking market has shifted from seller's market to buyer, which is characterized by the growth of banking capacity which is much faster than market growth (Bank Indonesia, 1997). In such conditions, the view of marketing (marketing point of view) is needed to win the competition. Traditional ways of working (expecting customers to come to the bank) must be abandoned if the bank does not want to lose the banking battle arena (Bank Indonesia, 1997)

Account Officers are management officers assigned to assist directors in handling tasks, especially those related to marketing and financing (Jusuf, 2008). Account Officers have a big role, because of their role in connecting banks with their customers. The Account Officer's task starts from finding, evaluating, evaluating, then proposing a customer financing proposal, and not stopping there. Account Officers must also maintain their customers to be able to return the funds borrowed to the bank (Jusuf, 2008). You can say Account Officers like consultants for banks. So as the spearhead of Bank Account Officers, they must have high integrity to the bank, not giving customers a random proposal that actually becomes a risk to the bank in the future (Osei-Nyarko, 2015).

Account Officers are the spearhead of any credit disbursement made at banks or other financial institutions (Osei-Nyarko, 2015), in which all activities start from the stage of debtor discovery and introduction which are carried out in a structured manner, analysis until the final stage, namely manager whether to provide financing or will refuse it (Jusuf, 2008).

According to Jusuf (2008), basically the role and function of an Account Officer are: (1). Manage Accounts, (2). Manage products, (3). Manage credit, (4). Manage sales and (5). Manage profitability. Seeing the function of the Account Officer, it can be said that the ideal Account Officer is one who has the following characteristics: (Jusuf, 2008).

1. Personal Characteristics.

a. Intelligence, both from an academic point of view and a practical point of view, an Account Officer must be able to apply his intelligence to solve problems.

b. Acting on common sense

c. Having curiosity.

d. Ability to listen

e. Ability to solve problems and analytical abilities

f. Results oriented 
g. Have self-motivation

h. Firm and Confident

i. Having good communication skills, the ability to manage time, adaptability, negotiation skills. 2. Technical Capability.

a. Understanding of a business in general

b. Ability to analyze financial statements, economics, knowledge of available sources of information, product knowledge, marketing and bookkeeping.

c. Get to know various aspects of various industries.

A reliable and strong account officer as a competitive advantage of financial institutions. Progressing and developing a bank, one of which is determined by the marketing strategy applied by management, and as the spearhead of the company's strategy so that bank business planning can be realized, is inseparable from the role of Account officers as bank marketers (Noor, 2015). The reliability of each individual Account Officer has become a necessity for both the company and the AO itself, because if he is able to achieve the target of the bank's desire it will have an impact on increasing the compensation received in the future. The high level of business competition in various industrial sector activities (high competitiveness) has a significant impact on the banking industry. The banking world in anticipation of this is required to be able to maintain the quality of service to customers, including through empowerment and services carried out by Account Officers. Improving the quality of human resources, especially Account Officers, can be done through education, training or reading various literature which is expected to improve knowledge, skills, attitude, and achievement (Noor, 2015)

According to Noor (2015), the requirement for an AO to be reliable and resilient must have the following characteristics :

1. able to know yourself and develop it

2. able to get to know the company and move it

3. able to get to know the work area

4. able to know the work environment and understand it

5. able to get to know customers and build them

6. able to know the product and improve it

7. able to get to know the market and analyze it

8. able to get to know competitors and anticipate possibilities (which will happen)

Thus, each financial institution will have a distinctive competitive advantage and cannot be replicated in their reliable and resilient AO (Peteraf, 1993). This condition will make financial institutions survive (in competition) for a relatively long time (Barney \& Hesterly, 2015); (Peteraf, 1993).

Asymmetric information. According to Diamond (1984), there is an information gap between those who need capital, financial intermediaries and capital providers. Supervision of capital owners to banks is a more established process compared to finance companies. One type of information issued by companies that can signal to parties outside the company is annual reports (Mcqueen, 2001). The company's drive to provide information is due to information asymmetry between companies and external parties (Dehlen, Zellweger, Kammerlander, \& Halter, 2014). Asymmetric information refers to situations and conditions where parties involved in (business) trade do not have sufficient information between one another (Rodrigues \& Galdi, 2017). Information asymmetry will appear when the debtor has far better information about his financial condition than the lender (bank). (Auronen, 2003) explained that it is quite difficult to distinguish good and bad debtors. Lenders have difficulty knowing whether the borrower will fail in the future. Lenders can try to overcome this problem by looking at past credit history with evidence of cash flow income (Samreen, Zaidi, \& Sarwar, 2013). However, this can only provide limited information.

People who have more information are in a position to negotiate the right conditions for transactions than others (Prado \& Martinelli, 2018). Conversely, those who lack information will make wrong decisions. Kipyego \& Wandera (2013) argued that adverse selection would indicate that when a 
lender cannot distinguish between good and bad borrowers, everything will be applied equally (Mugwe \& Oliweny, 2013). Onuko, Munir Muganda, \& Musiega (2015) states that if the borrower can provide the information needed when applying for a loan, the lender (the bank) can make the best decision regarding the loan application. When credit risk decreases, the level of NPL (ratio of nonperforming loans) decreases so that credit quality is maintained (Koju, Koju, \& Wang, 2018). Likewise, if a bank can make additional efforts to ensure all information needed during the credit assessment process, the credit risk associated with the prospective debtor can be maintained (García, Giménez, \& Guijarro, 2012).

Credit. Credit is one of the bank's services as a manifestation of the intermediary function (Scholtens \& van Wensveen, 2003). In addition, Credit is one of the main services of banking because it is the largest source of income among other banking services (Klein, 1971), is at the heart of the banking business (Yimka, Agbatogun, Abimbola, \& Adekunle, 2015) which aims to maximize corporate profits (Noman, Pervin, Chowdhury, \& Banna, 2015). According to Law Number 10 of 1998 (Article 21 paragraph 11) credit is the provision of money or equivalent claims, based on a loan agreement between banks and other parties that requires the borrower to repay the debt after a certain period of time with interest (Ministry of Finance, 1998).

According to Kasmir (2015), the elements in granting credit are (1). Trust, (2). Agreement, (3). Duration, (4). Risk, (5). Remuneration. While the purpose of Credit is (1). Seeking Profits, (2). Assisting customer business, (3). Helping the government (Kasmir, 2015). According to Kasmir (2015), credit functions include: (1). increase the use of money, (2). increase circulation and money traffic, (3). increase the utility of goods, (4). Increase the circulation of goods, (5). economic stability tool, (6). increase excitement, (7). increase income equity, and (8). improve international relations.

The decision to give credit by banks is generally full of risks, and requires a lot of attention and wisdom in its implementation (Owino, 2014). The success of each lending process is greatly influenced by the credit work team, but essentially still depends on the credit analysis process (initial) and the maintenance and monitoring process so that the credit process can run as expected.

According to Erdoğan (2014) and Baiden (2011), the principle of crediting known as the 5C principle is (1). Character, (2). Capacity, (3). Capital, (4). Condition of economy and (5). Collateral. This 5C principle is applied in the hope of being a reference material for bank credit analysts because banks certainly do not want to provide their credit to customers (Kasmir, 2015). For bankers, customers who meet the $5 \mathrm{C}$ criteria are the perfect people to get their financing. People like this are considered potential customers to be invited to work together or people who deserve credit distribution (Baiden, 2011). In short, people who can fulfill the 5C principle are ideal debtors.

Credit as a valuable "capital outflow". Credit is also called productive assets, because it can make money. Loans are also often called risk assets, because they are potentially non-refundable. Why is that? Because credit is the largest and most important source of income in the banking business (Klein, 1971). Loans are channeled from the capital deposited by customers' savings, bank capital and from other bank loans. Because of the nature of the loan, the legal obligation to be returned is in accordance with the applicable regulations. Because if not, then it has the potential to cause credit risk for credit providers (in this case the bank).

$5^{\prime} \mathrm{C}$ Principle is the initial door in processing all loan application files. The lender (account officer) will select loan proposals carefully based on the character, capacity, capital, economic conditions and guarantees provided (Baiden, 2011); (Erdoğan, 2014). Then in the credit journey, the account officer is obliged to monitor the use of credit provided (Spuchláková et al., 2015); (L. Nguyen, 2016); (DeYoung, 2017). As long as the credit has not been paid off, the risk remains and is the responsibility of the lender. In addition, the funds used are "capital" of the bank obtained from customer deposits, bank loans and bank capital itself.

Therefore, it is appropriate that credit will be so valuable and crucial, because from its origin it is very valuable, the process is very valuable, the monitoring is very valuable, and the return is also very crucial in the bank's operations. 
Credit Risk. The main risk faced by banks today is credit risk, because of the potential for default loans (principal, interest, commission) on time or in accordance with agreed terms (Grinis, 2015); (Klieštik \& Cúg, 2015). Therefore, the Bank is required to reserve loan losses to cover losses caused by loans (Svitek, 2011); (Balla \& Rose, 2011). Credit risk arises from debtors who cannot pay their obligations, or their financial capacity deteriorates resulting in economic losses for the bank.

Credit risk is the main source of risk for banks because of the bank's main function in intermediation activities, namely lending to parties who lack funds or deficits (Ikatan Bankir Indonesia, 2015). While credit risk according to Basel Committee (2000) is the potential that bank borrowers or partner parties fail to fulfill their obligations in accordance with agreed terms. According to Ahmed \& Malik (2015) credit risk is the most expensive risk in financial institutions and its influence is more significant than other risks because it directly threatens the solvency of the company. In addition, credit risk is also considered the biggest risk of all other risks that affect the bank's financial performance (Veizi, Mano, \& Koçiu, 2016).

One of the causes of credit risk is the concentration of funds available to debtors, geographical areas, products, types of financing, or certain business fields (Addae-Korankye, 2014). Thus, credit risk will eliminate the profitability of financial institutions because they are fully dependent on loan loans to increase their portfolio (Muhamet \& Arbana, 2016).

Moti et al. (2012) argue that smart and effective credit management is a key requirement for effective credit management. Furthermore, to minimize credit risk, banks must have greater attention to important factors such as debtor finances, past loans (Moti et al., 2012). Ahmed \& Malik (2015) argues that in maintaining credit risk is by conducting a credit management process by considering the credit period, customer appraisal, control of credit risk and Credit billing policies. Whereas Murigi \& Thuo (2018) argued that the environment is from credit risk (credit risk environment), credit appraisal process, credit administration, measurement and monitoring (credit administration, measurement and monitoring) and internal control (Internal Control over credit risk) influences credit risk assessment.

Previous research on credit risk. Wachira (2017) and Njeru et al. (2016) found that all commercial banks have a well-made credit policy that is strictly and consistently followed. Because if not, it will increase the ratio of non-performing loans (NPL) and reduce bank profitability (Kolapo, Ayeni, \& Oke, 2012); (Li \& Zou, 2014); (Hosna, Manzura, \& Juanjuan, 2009); (Onuko et al., 2015); (Haneef et al., 2012). Therefore, effective and efficient behavior (in the credit process) greatly affects bank profitability and continuity (Matu, 2008). Moti et al. (2012) also states that policies in the installment collection process have a significant influence on loan performance.

Thisika \& Jomo (2017); Kiplimo \& Kalio (2014); Njeru et al. (2016); Ahmed \& Malik (2015) found that an assessment (credit proposal) of a prospective debtor is a factor that influences loan performance. Financial institution losses are due to debtor defaults (Fun Ho \& Yusoff, 2009). Good management of loan portfolios (Haneef et al., 2012); and the quality of human resources (credit team) in fostering debtors influences loan performance. In addition, banks must determine non-performing credit indicators in credit risk management (Alshatti, 2015).

Good and continuous loan monitoring is the main key in the credit process. Wachira (2017) found that the majority of banks check and monitor post-disbursed loans. Kalu et al. (2018); Lagat et al. (2013) also found that the process of monitoring and mitigating credit risk has a positive relationship with financial performance. Maina et al. (2016) revealed that there is a strong relationship between credit risk monitoring, billing policy and loan arrears. Kimotho \& Gekara (2016); Alshatti (2015); Kibor et al. (2015) recommend that the need for supervision, standardization and policies in the credit process, because it is very influential on bank profitability.

However, Kithinji (2010); Ruziqa (2013); Embaye et al. (2017) found that bank profitability is not affected by credit risk management. Then (Lebbe et al., 2016); (Otieno et al., 2016) found that credit risk management did not significantly affect the credit performance of commercial banks. Maluni 
(2011) concludes that the level of problem loans is inversely proportional to credit risk management practices.

Credit risk management. Nikolaidou \& Vogiazas (2014) define credit risk management as a combination of tasks and coordinated activities to control and direct the risks faced by the organization through the incorporation of key risk management tactics and processes in relation to organizational objectives. The credit risk management model covers the existing systems, procedures and controls of the company to ensure efficient collection of customer payments and the risk of not paying (The Basel Committe, 2006). The purpose of implementing credit risk management is to mitigate the risk of default that can result in a reduction in the loan portfolio of lending institutions and the failure of lending to borrowers is an important activity in the management of financial institutions (Moti et al., 2012).

It is important to underline that risk management practices are not developed and aim to eliminate risk altogether but they aim to control opportunities and hazards that can lead to risk (Bezzina, Grima, \& Mamo, 2014). Kargi (2011) asserts that credit risk management will maximize the level of adjusted bank risk by maintaining credit risk exposure within acceptable limits to provide a framework for understanding the impact of credit risk management on bank profitability.

The guidelines for running credit risk are Basel accord, which discusses 12 risks faced by banks and credit risk is ranked first (The Basel Committe, 2006). Commercial banks are expected to follow these Basel accord practices in managing their credit risk. With effective credit risk management, banks will improve their health and profitability; and this in turn results in systemic stability and efficient capital allocation in an economic system (Psillaki, Tsolas, \& Margaritis, 2010). Gustafson et al. (2016) and Lagat et al. (2013) in his research found that banks must increase the frequency of monitoring as a manifestation of credit risk management practices for their customers, because the better the information update, the bank will provide early warning systems for how to deal with customers.

Previous research on credit risk management. Murigi \& Thuo (2018) stated that Internal Control over credit risk, Credit administration, measurement and monitoring in credit risk management greatly affect the level of loan performance. Cerqueiro, Ongena, \& Roszbach (2014); Kiplimo \& Kalio (2014); Gakure, Ngugi, Ndwiga, \& Waithaka (2012); Moti et al. (2012) found that credit risk management practices significantly affect loan performance; increase bank profitability (Li \& Zou, 2014); (Hosna et al., 2009); (Kimotho \& Gekara, 2016); (Alshatti, 2015); reduce the ratio of nonperforming loans (Onuko et al., 2015); (Haneef et al., 2012); and will increase cost efficiency as a consequence of a decrease in NPL (Krasnikov, Jayachandran, \& Kumar, 2009). In addition, Kithinji (2010) found that bank profitability is not influenced by credit risk management; then Sampagnaro, Meles, \& Verdoliva (2015) found that monitoring does not affect bank performance and credit risk. Then Lebbe et al. (2016); Otieno et al. (2016) found that credit risk management did not significantly affect the credit performance of commercial banks. And Maluni (2011) concluded that the level of problem loans was inversely proportional to credit risk management practices.

AO training and upgrading skills. In the credit process, the ability of credit providers is very important. Marketing (account officer) is at the forefront as the spearhead of financial institutions. Process credit applications, monitor loans, collect installments up to customer development (Nsiah, 2017); (Schwarz, 2011); (Osei-Nyarko, 2015). Therefore, AO is required to have good skills and knowledge about credit and things that support the credit process (Baklouti \& Baccar, 2013). As an extension of the bank, AO is expected to gather information about the financing process, both from the debtor and from other parties related to the credit process (Wachira, 2017).

AO must have knowledge for the credit assessment process (Njeru et al., 2016); (Kiplimo \& Kalio, 2014); (Ahmed \& Malik, 2015); (Thisika \& Jomo, 2017); carry out the monitoring process (Murigi \& Thuo, 2018); (Lagat et al., 2013); (Kimotho \& Gekara, 2016); (Kalu et al., 2018); (Gustafson et al., 2016); and carry out the billing process (Moti et al., 2012). All of these skills are needed to control 
credit risk that might occur (Maina et al., 2016); (Kimotho \& Gekara, 2016), because it will affect loan performance and is directly proportional to the bank's profitability.

AO must also have the ability to meet bank needs for information asymmetry, including collecting information about the applicant's capabilities and presenting it to the credit committee for approval; and check credit exposures and enforce rules in the event of a payment delay (Agier, 2012). In short, the ability of loan officers greatly affects the performance and the credit process itself (Aliija \& Muhangi, 2017). In addition, AO must be able to educate its debtors about things that allow the occurrence of non-performing loans, so that it is expected that the system (credit) that has been designed can run properly (Nyasaka, 2017). One way to improve account officer knowledge is by providing training and upgrading skills, especially in the credit process. Through training media, AO skills will be more honed, more updated on the latest credit policies and at the same time strengthen friendship with fellow AOs. Thus, it is expected that AO can maximize its performance and will automatically have an impact on credit performance and bank profitability (Agier, 2012).

In general, there has been a lot of research in the HR field about the influence of training on employee performance and productivity. Like Shem \& Ngussa (2017) who found that regular training in terms of orientation, off-the-job training, workplace training and training / assistance to employees increased employee effectiveness and productivity. Then Anitha \& Kumar (2016); Al-Mzary, Alrifai, \& Momany (2015); (Onyango \& Wanyoike, 2014) found that training will improve employee performance and productivity.

Business mentoring. Mentoring is an approach to human resource development and important aspects of knowledge management that need to be considered by all educational institutions and institutions that want to improve their efficiency (Moed, 2012); (McLaughlin, 2010). Mentoring relationships mean usually someone who has experience helping others (or many) to study, integrate into a corporate community, etc. (Bozeman \& Feeney, 2007). Debtors who have used business mentors can play a role in all areas of the company's business with a particular focus, namely in the areas of finance, sales or marketing. Mentors can help to conduct a SWOT analysis, including staff knowledge and skills gaps. It is very important how-to mentor beginner SME entrepreneurs in building teams, developing business plans, product development or sales and marketing strategies. They also help companies prepare investment plans and guide them in implementing them.

The companion role (in business mentoring) greatly determines the success of the debtor to develop, because the companion is expected to function as a motivator, conduct business consultations, assist debtors to promote superior products and improve the quality of debtors through business training, managerial skills and improvement of the debtor marketing network. In connection with assistance, the facilitation process and the support of various aspects for the development of the business will be provided by a consultant or debtor companion for business actors to be able to develop and run according to their business lines. Basically every business will experience problems that can interfere with the business itself, both aspects of capital or financing, management (HR, finance, marketing) and then product problems and others. The role of mentoring will provide input and motivate businesses to grow and advance.

The Indonesian government has issued SKKNI number 181 of 2017 concerning KUMKM Assistance, which further reinforces mentoring services to increase the business capacity of SMEs. In this SKKNI, the government outlines the ways of mentoring among mentoring institutional management and business and product legality, mentoring operations management, human resource management, marketing management, financial management and financing, and production management (Kementrian Tenaga Kerja, 2017). In this study, the authors focus on mentoring the field of financial management and financing, assuming the main problem of the debtor is the difficulty in managing finances and financing problems.

Customer relationship management. Customer Relationship Management (CRM) is a comprehensive strategy and process that allows organizations to identify, obtain, maintain and maintain profitable customers (Mohamad, Othman, Jabar, \& Majid, 2014). CRM is also a company work program whose 
purpose is to create satisfaction and long-term relationships with customers. This concept integrates several functional areas of the company in order to gain competitive advantage (Chang \& Chen, 2007); (T. H. Nguyen, Sherif, \& Newby, 2007); (Payne \& Frow, 2005).

One factor in the failure of debtors to repay loans from financial institutions is the lack of monitors from the lenders (Abor, 2007). Debtors are left alone after getting funds. This condition is exacerbated by apathy from debtors who are indifferent to this (DeYoung, 2017). They seem to think that the absence of intense communication during the loan period will not affect the quality of the loan (DeYoung, 2017), even though this will affect the quality of the loan and increase the bank's risk. Some opinions and research suggest the need to establish relationships between lenders and debtors due to imperfect information. Asymmetric information is not only needed when processing loans, but will still occur until the credit is paid off (Kipyego \& Wandera, 2013). Ahn \& Choi (2009); Coleman, Esho, \& Sharpe (2006) argue that monitoring loans is very important for loan sustainability and the continuity of the debtor's business; transaction changes and collateral (Mester, Nakamura, \& Renault, 2007); also to monitor credit collateral (Cerqueiro et al., 2014).

Through the implementation of CRM, all information about the customer, about shopping behavior, products that are commonly consumed, etc. will be known (Agrawal, 2004). Later this information will be used to increase knowledge of customers and build communication with the aim of creating value and customer satisfaction, customer loyalty, profits and long-term relationships with customers and other key stakeholders (Agrawal, 2004).

Previous research on capital outflow monitoring management (COMM). Credit risk will continue to run during the credit process. AO must be able to educate its debtors about things that allow nonperforming loans to occur, so it is expected that the system (credit) that has been designed can run as it should (Nyasaka, 2017).

Wachira (2017) found that the majority of banks check and monitor loans after being disbursed, because good and continuous loan monitoring is the main key in the credit process. Management must develop policies and procedures, establish a credit limit as a whole, have a system to monitor individual credit conditions and an independent internal control system to conduct a continuous assessment of the bank's credit risk management process (Murigi \& Thuo, 2018).

As an extension of the bank, $\mathrm{AO}$ is expected to be able to collect information about the financing process, things that cause non-performing loans, both from debtors and from other parties related to the credit process (Wachira, 2017); (Alshatti, 2015). In this day and age, it is very easy to access data related to debtors or prospective borrowers, so that it is not a reason the bank does not carry out the monitoring process, checks and checks the information of debtors and prospective borrowers (Härle, Havas, Kremer, Rona, \& Samandari, 2015). However, all of that must be accompanied by the skills, experience and knowledge of marketing itself in carrying out the credit process.

Achi \& Sleilati (2016) found that coaching activities and training for marketing (AO) will increase motivation, creativity and work performance. Banks must hold seminars or training to up-date the latest credit guidelines to increase their knowledge of credit risk management with a view to ensuring customer satisfaction (Danjuma, Kola, Magaji, \& Kumshe, 2016). If the credit team rarely gets training on credit risk, it is feared that $\mathrm{AO}$ will be wrong in practicing credit risk in the field. The training is also adjusted to the cases encountered in the field (Raj \& Sindhu, 2013).

In practice, the bank (in this case the $\mathrm{AO}$ and the credit team) can use computer assistance (which has been programmed) as a database to predict credit risk, monitoring, and credit processes (Addo, Guegan, \& Hassani, 2018); (Khandani, Kim, \& Lo, 2010). The computer is equipped with algorithms derived from credit risk so that in its implementation it will greatly assist the credit team in making decisions (Addo et al., 2018).

Monitoring also allows parties to be more aware of the current conditions of the debtor so as to bridge the credit risk management process as an effort to reduce the level of non-performing loans (Idris \& Nayan, 2016). 
Besides internal processes, it is also important in credit risk management is the debtor's maintenance process. One way is to provide training (Ssekiziyivu, Bananuka, Nabeta, \& Tumwebaze, 2018), so that the debtor can understand how to use their loan facilities. With the relationship between the bank and the debtor, the debtor feels an important asset for the company, because they feel cared for and of course this condition will increase the debtor's loyalty to the company (Limakrisna, 2018); (Kristian \& Panjaitan, 2014); (Keisidou, Sarigiannidis, Maditinos, \& Thalassinos, 2013).

In connection with the credit risk management process, the bank must maintain credit risk exposure so that it can maximize loan repayments. Therefore, it is absolutely necessary to cooperate with all parties (especially AO) in carrying out and complying with all credit requirements and credit policies in order to create better credit performance (Mumbi \& Omagwa, 2017); (Asante, 2015).

Concept synthesis. Briefly the synthesis of the Capital Outflow monitoring management (COMM) concept can be seen in the following table:

Table 1. New Concept Synthesis (Capital Outflow monitoring management / COMM)

\begin{tabular}{|c|c|c|}
\hline $\mathrm{NO}$ & CONCEPT NAME & RESEARCHER \\
\hline 1 & Internal Maintenance & \\
\hline & Credit Risk Management & $\begin{array}{l}\text { Wachira (2017); Murigi \& Thuo } \\
\text { (2018) }\end{array}$ \\
\hline & AO training and upgrading skill & $\begin{array}{l}\text { Al-Mzary et al. (2015); Agier (2012); } \\
\text { Baklouti \& Baccar (2013) }\end{array}$ \\
\hline 2 & External Maintenance & \\
\hline & $\begin{array}{r}\text { Business Mentoring } \\
\text { Customer Relationship } \\
\text { Management }\end{array}$ & $\begin{array}{l}\text { Kementrian Tenaga Kerja (2017) } \\
\text { Mohamad et al. (2014). Wachira } \\
(2017)\end{array}$ \\
\hline
\end{tabular}

Source: Concept development (2018)

Figure 1. Synthesis of Capital Outflow Monitoring Management (COMM) Concept

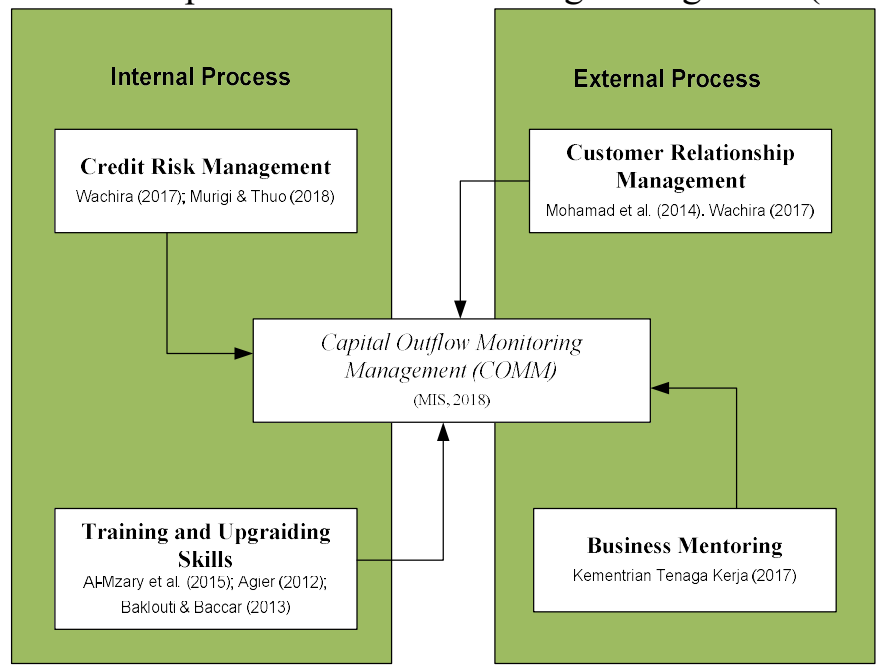

Source: Concept development (2018)

Ontology: Capital outflow monitoring management (COMM) is a concept in which AO is able to foster and guide debtors in conducting business activities through two processes, namely internal processes (application of credit risk management, improvement of AO skills) and external processes (through the implementation of customer relationship management and business.

Loan Performance. Loan Performance is the condition of the loan in a smooth condition. Banks and other financial institutions always avoid non-performing loans, because of credit risk caused by 
uncollectible principal and interest on loans (Asfaw, Bogale, \& Teame, 2016); (Dung, 2014). Credit performance also refers to the level of profitability or return on investment in various loan products (Liang, Huang, Liao, \& Gao, 2017); (Taiwo et al., 2017). Credit health is a benchmark to assess the level of likelihood of receiving funds invested in productive assets (principal including interest) based on certain criteria. In Indonesia, the quality of earning assets is valued based on the level of bills (Bank Indonesia, 2011), and the soundness of credit is measured by the level of collectability of loans. The purpose of determining credit collectability is to determine credit quality so that banks can anticipate risk early because credit risk can affect the business continuity of the bank. Besides that, the determination of credit collectability is used to determine the reserve level of potential losses due to non-performing loans (Bank Indonesia, 2012).

Determination of credit quality refers to Bank Indonesia provisions, namely PBI number 14/15 / PBI / 2012 concerning Asset Quality Rating for Commercial Banks (Bank Indonesia, 2012) and SE BI number 7/3 / DPNP dated January 31, 2005 concerning Asset Quality Rating for Commercial Banks (Bank Indonesia, 2005). In accordance with PBI number 14/15 / PBI / 2012, credit quality can be determined based on three parameters consisting of (Bank Indonesia, 2012): (1). Business Prospects, (2). Debtor Performance and (3). Credit quality.

Determination of credit quality is carried out by considering the materiality and significance of the valuation factor and the component to the characteristics of the debtor concerned. For a certain amount of micro, small and medium credit, the determination of credit quality can only be based on the accuracy of installment payments. Then, credit is categorized as problematic (Non Performing Loan / NPL) if it is not paid for more than 90 days (Bank Indonesia, 2012). The purpose of the classification is to determine the level of reserve potential losses due to non-performing loans.

Non-Performing Loan (NPL). Non-performing loans are increasing due to lack of application of credit risk management practices, which in turn threatens bank profitability (Nyasaka, 2017). This condition signals the banking sector to avoid bad credit by applying the methods suggested by the central bank (Haneef et al., 2012). The causes of bad loans are usually associated with a lack of effective supervision from banks, lack of effective lending assistance, weakness in legal infrastructure, and lack of an effective debt recovery strategy (Adhikary, 2006).

For this reason, the level of NPL will be of particular concern because NPLs in the banking system are bank failures and also symptoms of a country's economic slowdown (Lata, 2015). This is because most of the financial performance of commercial banks is measured by the level of profitability and NPL has a major contribution to the level of profitability of banks (Balasubramaniam, 2013). Saba, Kouser, \& Azeem (2012) stated that an increase in NPL was a manifestation of the failure to implement a credit policy. Khemraj \& Pasha (2009) explained that high NPL percentages are often associated with bank performance problems and financial crises in developing and developed countries.

The Non-Performing Loan (NPL) ratio measures the risk of a bank's credit portfolio by looking at the failure of the debtor to fulfill its obligations to pay the loan principal or interest (D'Hulster, Letelier, \& Valeria, 2014). The bank's NPL ratio must always be maintained so as not to exceed 5\% in accordance with the regulations set by Bank Indonesia (Bank Indonesia, 2012). NPL can illustrate how far the prudential principle is applied by banks in channeling and managing credit (Gunadi \& Taruna, 2015). NPL will also affect the banking system and affect the economic system and the welfare of citizens. Therefore, NPLs can cause inefficiencies in the banking sector.

NPL reflects credit risk. The smaller the NPL, the smaller the credit risk borne by the bank, because NPL greatly affects the level of bank profitability (Nyarko-baasi, 2018); (Akter \& Roy, 2017); (Kingu, Macha, \& Gwahula, 2018); (Vinh, 2017); (Ozili, 2017); (Mwinlaaru, Ofori, Adiyiah, \& Idun, 2016); (Bace, 2016). Thus, if the NPL is high then the bank's profitability will decrease, and the company's performance will decrease (Chimkono \& Muturi, 2016); (Etale, Ayunku, \& Etale, 2016); (Chege \& Bichanga, 2017); (Afriyie \& Akotey, 2013); (Bhattarai, 2016). However, Adebisi \& 
Benjamin (2015), Güneş (2015), Samırkaş, Evci, \& Ergün (2014) found no effect between NPLs and Return on Equity (ROE).

Effect of Credit Risk on loan performance. Wachira (2017); Njeru et al. (2016) found that all commercial banks have a well-made credit policy that is strictly and consistently followed. Because if not, it will increase the ratio of non-performing loans (NPL) and reduce bank profitability (Kolapo et al., 2012); (Li \& Zou, 2014); (Hosna et al., 2009); (Onuko et al., 2015); (Haneef et al., 2012). Therefore, effective and efficient behavior (in the credit process) greatly affects bank profitability and continuity (Matu, 2008). (Moti et al., 2012) also stated that policies in the installment collection process also have a significant influence on loan performance.

Thisika \& Jomo (2017); Kiplimo \& Kalio (2014); Njeru et al. (2016); Ahmed \& Malik (2015) found that the assessment (credit proposal) of prospective borrowers is a factor that influences loan performance, given the loss of financial institutions is due to default (Fun Ho \& Yusoff, 2009). (Haneef et al., 2012) found in his research that good loan portfolio management and the quality of human resources (credit team) in fostering debtors affect loan performance. In addition, banks must determine non-performing credit indicators in credit risk management (Alshatti, 2015).

Good and continuous loan monitoring is the main key in the credit process. Wachira (2017) found that the majority of banks check and monitor post-disbursed loans. Kalu et al. (2018); Lagat et al. (2013) also found that the process of monitoring and mitigating credit risk has a positive relationship with financial performance. (Maina et al., 2016) revealed that there is a strong relationship between monitoring credit risk, billing policy and loan arrears.

Kimotho \& Gekara (2016); Alshatti (2015); (Kibor et al., 2015) recommends that the need for supervision, standardization and policies in the credit process, because it is very influential on bank profitability.

However, Kithinji (2010); Ruziqa (2013) found that bank profitability is not influenced by credit risk management. Then Lebbe et al. (2016); Otieno et al. (2016) found that credit risk management did not significantly affect the credit performance of commercial banks. And Maluni (2011) concluded that the level of problem loans was inversely proportional to credit risk management practices.

From the views above, this study proposes Hypothesis 1: credit risk has a positive effect on loan performance.

Effect of Credit Risk Management on loan performance moderated by Capital outflow monitoring management (COMM). Credit risk will continue to run during the credit process. AO must be able to educate its debtors about things that allow non-performing loans to occur, so it is expected that the system (credit) that has been designed can run as it should (Nyasaka, 2017).

Wachira (2017) found that the majority of banks check and monitor loans after being disbursed, because good and continuous loan monitoring is the main key in the credit process. Management must develop policies and procedures, set a credit limit as a whole, have a system to monitor individual credit conditions and an independent internal control system to carry out continuous assessments of the bank's credit risk management process (Murigi \& Thuo, 2018).

As an extension of the bank, $\mathrm{AO}$ is expected to be able to collect information about the financing process, things that cause non-performing loans, both from debtors and from other parties related to the credit process (Wachira, 2017); (Alshatti, 2015). Today, it is very easy to access data related to debtors or prospective borrowers, so that it is not a reason for banks not to monitor, check and check debtor information and prospective borrowers (Härle et al., 2015). However, all of that must be accompanied by the skills, experience and knowledge of marketing itself in carrying out the credit process.

Achi \& Sleilati (2016) found that coaching activities and training for marketing (AO) will increase motivation, creativity and work performance. Banks must hold seminars or training to up-date the latest credit guidelines to increase their knowledge of credit risk management with a view to ensuring customer satisfaction (Danjuma et al., 2016). If the credit team rarely gets training on credit risk, it is 
feared that $\mathrm{AO}$ will be wrong in practicing credit risk in the field. The training is also adjusted to the cases encountered in the field (Raj \& Sindhu, 2013).

In practice, the bank (in this case AO and the credit team) can use computer assistance (which has been programmed) as a database to predict credit risk, monitoring, and credit processes (Addo et al., 2018); (Khandani et al., 2010). The computer is equipped with algorithms derived from credit risk so that in its implementation it will greatly assist the credit team in making decisions (Addo et al., 2018). Monitoring also allows parties to be more aware of the current conditions of the debtor so as to bridge the credit risk management process as an effort to reduce the level of non-performing loans (Idris \& Nayan, 2016).

Besides internal processes, it is also important in credit risk management is the debtor's maintenance process. One way is by giving training (Ssekiziyivu et al., 2018), so that debtors can understand how to use their loan facilities. With the relationship between the bank and the debtor, the debtor feels an important asset for the company, because they feel cared for and of course this condition will increase the debtor's loyalty to the company (Limakrisna, 2018); (Kristian \& Panjaitan, 2014); (Keisidou et al., 2013).

In connection with the credit risk management process, the bank must maintain credit risk exposure so that it can maximize loan repayments. Therefore, it is absolutely necessary to cooperate with all parties (especially AO) in carrying out and complying with all credit requirements and credit policies in order to create better credit performance (Mumbi \& Omagwa, 2017); (Asante, 2015).

From the views above, this study proposes Hypothesis 2: credit risk has a positive and significant effect on loan performance which is moderated by capital outflow monitoring management (COMM).

Figure 2. Conceptual framework

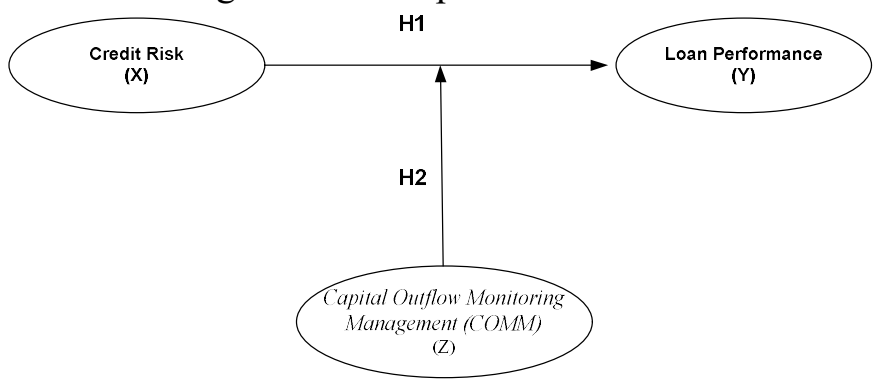

Source: concept development (2018)

\section{Research Methodology}

This research is an explanatory research conducted in two stages. The first stage emphasizes quantitative data collection and analysis then continues with a qualitative approach to further explain quantitative findings. (Lodico, Spaulding, \& Voegtle, 2006).

This research was carried out in Makassar City, South Sulawesi. Research time lasts for 3 (three) months.

The population in this study were all members of the Commercial Account Association (AAO) organization (which processes working capital and investment loans) of the BRI Regional Office of Makassar.

The population in this study are all members of the Association Account Officer (AAO) Commercial Retail (which processes working capital and investment loans) BRI Makassar Regional Office in 2009

Sampling is done using saturated sampling method, in which all populations are taken as a sample and the population is below 100 respondents (Lodico et al., 2006). Because there are only 50 active members, and adjusted to the research needs, the number of samples studied was 46 people.

The type of data in this study are primary and secondary data. 
Sources of data in this study were obtained from answers to questionnaires distributed to respondents who came from the Commercial Retail Association Account Officer (AAO) force of the year 2009 Makassar BRI Regional Office.

The method used to collect data in this study is filling out questionnaires and interviews. Research Variables and Operational Definition.

a. Credit risk : Is a risk that will occur if the debtor fails to pay the loan installment obligation.

b. Capital outflow monitoring management (COMM) : It is a concept in which AO is able to foster and guide debtors in conducting business activities through two processes, namely internal processes (application of credit risk management, improvement of AO skills) and external processes (through the implementation of customer relationship management and business mentoring).

c. Loan performance : Debtor loan conditions are measured through business prospects, debtor performance and credit quality.

Research Instruments.

Credit risk. The concept of credit risk in this study uses a measurement indicator adapted from the opinions of Ahmed \& Malik (2015) and Murigi \& Thuo (2018), namely (1). Credit term, (2). Credit assessment, (3). Billing policy, (4). Credit risk environment, (5). Credit administration.

The above credit risk variables are measured using an interval scale between 1 to 5 . The lowest score (1) of the respondents' answers which shows the very low credit risk that exists, whereas the highest score (5) shows the very high credit risk that exists.

Capital outflow monitoring management (COMM). The concept of Capital outflow monitoring management (COMM) in this study uses measurement indicators adapted from the concept of credit risk management (Wachira, 2017); (Murigi \& Thuo, 2018); Training and upgrading skills (Katerega, Ngoma, Masaba, Nangoli, \& Waswa, 2015); (Agier, 2012); (Baklouti \& Baccar, 2013); customer relationship management (Mohamad et al., 2014); (Wachira, 2017) and Indonesian National Work Competency Standards (SKKNI) number 181 in 2017 (Kementrian Tenaga Kerja, 2017), namely: (1). Focused on the debtor, (2). Internal control of loans, (3). Upgrading AO skills; (4). Debtor assistance; (5). Debtor training

The Capital outflow monitoring management (COMM) variable above was measured using an interval scale between 1 to 3 . The lowest score (1) from the respondents' answers which showed the very low Capital outflow monitoring management (COMM), the highest score (3) shows the very high Capital outflow monitoring management (COMM) available.

Loan performance. The variable loan performance in this study was measured by indicators adapted from PBI number 14/15 / PBI / 2012 (Bank Indonesia, 2012), namely: (1). Business prospect; (2). Debtor Performance; (3). Credit quality.

The measurement of loan performance variables is done using an interval scale between 1 to 5 . The lowest score (1) shows the very low loan performance and the highest score (5) shows the high loan performance. 
Table 3. Construct, indicators and sources

\begin{tabular}{|c|c|c|c|}
\hline No & Construct & indicators & sources \\
\hline 1. & Credit risk & $\begin{array}{ll}- & \text { Credit term, } \\
\text { - } & \text { Credit assessment, } \\
\text { - } & \text { Billing policy, } \\
\text { - } & \text { Credit risk } \\
\text { environment, }\end{array}$ & $\begin{array}{l}\text { Ahmed \& Malik (2015) and } \\
\text { Murigi \& Thuo (2018) }\end{array}$ \\
\hline 2. & $\begin{array}{l}\text { Capital } \\
\text { outflow } \\
\text { monitoring } \\
\text { management } \\
\text { (COMM) }\end{array}$ & $\begin{array}{ll}\text { - } & \text { Credit administration. } \\
\text { - } & \text { Focused on the debtor, } \\
\text { - } & \text { Internal loan control } \\
\text { - } & \text { Ugraiding AO skills } \\
\text { - } & \text { Debtor assistance } \\
\text { - } & \text { Debtor training }\end{array}$ & $\begin{array}{l}\text { (Wachira, 2017); (Murigi \& } \\
\text { Thuo, 2018); } \\
\text { (Katerega et al., 2015); } \\
\text { (Agier, 2012); (Baklouti \& } \\
\text { Baccar, 2013) } \\
\text { (Mohamad et al., 2014). } \\
\text { (Kementrian Tenaga Kerja, } \\
\text { 2017) }\end{array}$ \\
\hline 3 & $\begin{array}{l}\text { loan } \\
\text { performance }\end{array}$ & $\begin{array}{ll}\text { - } & \text { Business prospect; } \\
\text { - } & \text { Debtor Performance; } \\
& \text { Credit quality }\end{array}$ & $\begin{array}{l}\text { PBI nomor 14/15/PBI/2012 } \\
\text { (Bank Indonesia, 2012) }\end{array}$ \\
\hline
\end{tabular}

Source: concept development (2018)

Data analysis method uses statistical methods with the following testing stages : Construction Validity Test, Reliability Test, Goodness of Fit Model Test and determinant coefficient test. (Latan \& Ghozali, 2015)

The effect of Credit Risk on Loan Performance which is moderated by Capital Outflow Monitoring Management (COMM) is done by analyzing respondents' answers to the questions given. Then the results are processed using the help of Smart PLS 3.0 software

\section{Results and discussion}

The population in this study were all members of the Associate Account Officer (AAO) Commercial Retail (which processes working capital and investment loans) BRI Makassar Regional Office in 2009. In accordance with the calculation of the sample using saturated sample methods, and adjusted to the needs of the research then the sample will 46 people were studied (out of 50 people who were active in the 2009 AAO force). Respondents spread to branch offices or sub-branch offices located in the city of Makassar (Ahmad Yani, Panakkukang, Tamalanrea) and regency cities within the scope of the Makassar Regional Office (Gowa, Pangkep, Barru, Pare-pare, Sidrap, Pinrang, Palopo, Bone, Sengkang, Polewali, Mamuju, Takalar, Jeneponto, Sinjai, Watampone, Ambon, Kendari, Bau-bau). The details are as follows : 
Table 4. Description of Respondents

\begin{tabular}{|c|c|c|c|c|}
\hline No & \multicolumn{2}{|c|}{ Information } & total & Percentage \\
\hline \multirow{2}{*}{1} & \multirow{2}{*}{ Gender } & Male & 44 & $95,7 \%$ \\
\hline & & Female & 2 & $4,3 \%$ \\
\hline \multirow{2}{*}{2} & \multirow{2}{*}{$\begin{array}{l}\text { Field of } \\
\text { Concentration }\end{array}$} & $\begin{array}{l}\text { Commercial } \\
\text { Retail }\end{array}$ & 42 & $91,3 \%$ \\
\hline & & $\begin{array}{l}\text { Other } \\
\text { (medium) }\end{array}$ & 4 & $8,7 \%$ \\
\hline \multirow{2}{*}{3} & \multirow{2}{*}{ last education } & Bachelor & 46 & $100,0 \%$ \\
\hline & & postgraduate & & $0,0 \%$ \\
\hline \multirow{4}{*}{4} & \multirow{4}{*}{ Age } & $<20$ thn & _ & $0,0 \%$ \\
\hline & & $21-30$ & 3 & $6,5 \%$ \\
\hline & & $31-40$ & 43 & $93,5 \%$ \\
\hline & & $41-50$ & - & $0,0 \%$ \\
\hline \multirow{4}{*}{5} & \multirow{4}{*}{ Long serving } & $6-10$ & 46 & $100,0 \%$ \\
\hline & & $11-15$ & - & $0,0 \%$ \\
\hline & & $16-20$ & _ & $0,0 \%$ \\
\hline & & $>21$ & - & $0,0 \%$ \\
\hline & & Total & 46 & $100,0 \%$ \\
\hline
\end{tabular}

Source: Data processed (2018)

According to table 4, respondents who were male were 44 people $(95.7 \%)$ and women were 2 people (4.3\%). 42 people $(91.3 \%)$ were positioned as AAO Commercial Retail Loans and 4 people $(8.7 \%)$ were positioned as AAO Secondary Credit. In terms of recent education, all respondents in this study $(100 \%)$ had the last degree of education. In terms of age, 3 people $(6.5 \%)$ were in the age range of 21-30 years, while 43 people (93.5\%) were in the age range of 31-40 years. As for the length of time of office, all respondents (46 people) have served as AAO for 9 years. Looking at the description of respondents in table 4, it can be ascertained that the respondent's strength is very good because it has been experienced since 2009 in processing credit (some have experienced being AO before working at BRI) and are concentrated in Commercial Retail and Medium Credit.

The following is the conceptual framework in this study 
Figure 3. Conceptual Framework for Research

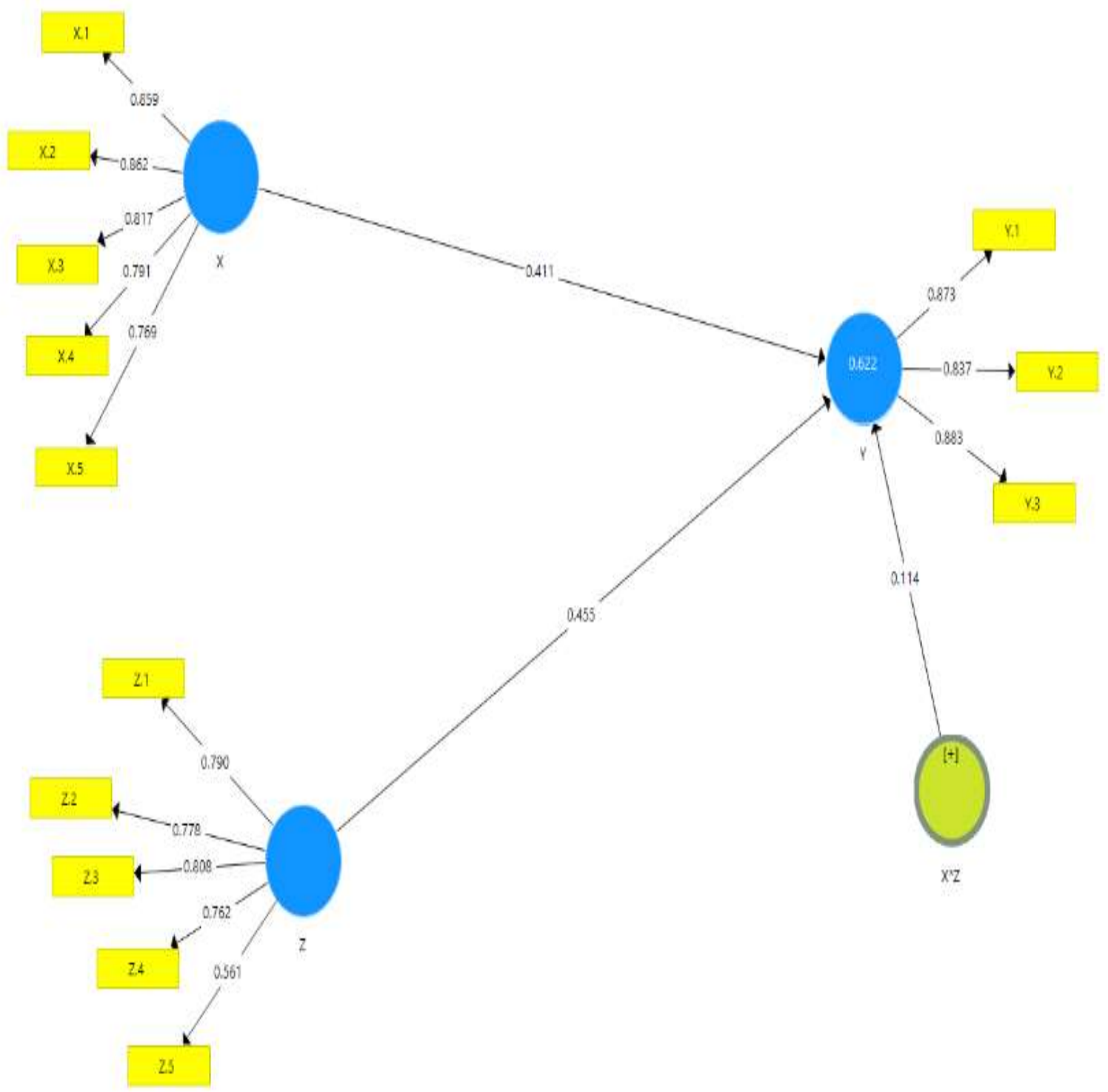

Source: Data processed (2018)

Based on Figure 3, in this study there are 3 variables :

a. Variable X (credit risk) which acts as an independent variable, which has 5 indicators, namely X.1 (Credit period), X.2 (Credit assessment), X.3 (Billing policy), X.4 (Risk environment credit), and X.5 (Credit administration)

b. Variable Y (Loan Performance) which acts as the dependent variable, which has 3 indicators, namely Y.1 (Business Prospect), Y.2 (Debtor Performance), Y.3 (Credit Quality).

c. Variable Z (capital outflow monitoring management / COMM which acts as a moderator variable, which has 5 indicators namely Z.1 (Centralized on the debtor), Z.2 (Internal control of the loan), Z.3 (Ugraiding skill AO), Z .4 (debtor assistance), Z.5 (debtor training) 
Table 5. Test Results of the Coefficients Path

\begin{tabular}{|l|c|r|r|r|}
\hline \multicolumn{1}{|c|}{ Dependent Variable } & \multicolumn{1}{|c|}{$\begin{array}{c}\text { Independent } \\
\text { Variables }\end{array}$} & $\begin{array}{c}\text { Original } \\
\text { Sample } \\
(\mathrm{O})\end{array}$ & $\begin{array}{c}\mathrm{T} \\
\text { Statistics } \\
(\mid \mathrm{O} / \mathrm{STDE} \\
\mathrm{V} \mid)\end{array}$ & $\begin{array}{c}\mathrm{P} \\
\text { Values }\end{array}$ \\
\hline Credit Risk $(X)$ & $\begin{array}{c}\text { Loan } \\
\text { Performance }(Y)\end{array}$ & 0.411 & 3.140 & 0.002 \\
\hline $\begin{array}{l}\text { Capital Outflow } \\
\text { Monitoring Management } \\
\text { (COMM) / (Z) }\end{array}$ & $\begin{array}{c}\text { Loan } \\
\text { Performance }(Y)\end{array}$ & 0.455 & 3.887 & 0.000 \\
\hline $\begin{array}{l}\text { Credit Risk }(X) * \text { Capital } \\
\text { Outflow Monitoring } \\
\text { Management }(\text { COMM) / }(Z)\end{array}$ & $\begin{array}{c}\text { Loan } \\
\text { Performance }(Y)\end{array}$ & 0.114 & 0.971 & 0.332 \\
\hline
\end{tabular}

Source: Data processed (2018)

Based on table 5, it can be seen that the $\mathrm{T}$ Statistics value for variables $\mathrm{X}$ and $\mathrm{Z}$ is greater than the $\mathrm{T}$ table value (1.96 for alpha 5\%), while the value of $\mathrm{X} * \mathrm{Z}$ is smaller than T-Table (1.96 for alpha 5\%). Then the original sample values for $\mathrm{X}$ and $\mathrm{Y}$ variables are greater than $\mathrm{P}$-values, and $\mathrm{X} * \mathrm{Z}$ values are smaller than P-values.

Effect of Credit Risk on Loan Performance. Based on the results in table 14, the original value of the sample influence of Credit Risk on Loan Performance of 0.411 is greater than the value of P-values of 0.002. therefore, hypothesis 1 explains that credit risk has a positive effect on loan performance. The amount of influence credit has on the Loan Performance is 0.411 or $41.1 \%$, which means that if the Credit Risk value is increased, the value of the Loan Performance will increase by $41.1 \%$.

This result is in accordance with Wachira (2017); Njeru et al. (2016); Kolapo et al. (2012); Li \& Zou (2014); Hosna et al. (2009); Onuko et al. (2015); Haneef et al. (2012). In addition, the results of this research are also in accordance with the results of research conducted by Matu (2008); Moti et al. (2012); Thisika \& Jomo (2017); Kiplimo \& Kalio (2014); Ahmed \& Malik (2015); Fun Ho \& Yusoff (2009); Alshatti (2015), and also research by Kalu et al. (2018); Lagat et al. (2013); Maina et al. (2016); Kimotho \& Gekara (2016). However, the results of this research reject the results of research conducted by Kithinji (2010); Ruziqa (2013); Lebbe et al. (2016); Otieno et al. (2016) and Maluni (2011).

AAO in processing credit applications is always based on the principle of prudence, which is embodied in the principle of $5 \mathrm{C}$. Thus, credit risk can be managed properly. The fundamental reason why credit risk (credit risk) must be maintained is to improve the quality of bank credit. If a bank's loan portfolio is good, it will be a success because it can improve the health of the bank itself.

Effect of Credit Risk on Loan Performance moderated by Capital Outflow Monitoring Management (COMM). Based on the results in table 14, the original value of the sample effect of Credit Risk on Loan Performance which is moderated by Capital outflow monitoring management (COMM) of 0.114 is smaller than the $0.332 \mathrm{P}$-values. Therefore, hypothesis 2 which explains that Credit Risk has a positive influence on loan performance which is moderated by Capital outflow monitoring management (COMM) is rejected. The amount of influence credit has on Loan Performance is 0.114 or $11.4 \%$, which means that if the Credit Risk and Capital outflow monitoring management (COMM) value increases, the value of the Loan Performance will decrease by $11.4 \%$.

This result rejects research conducted by Nyasaka (2017); Wachira (2017); Murigi \& Thuo (2018); Alshatti (2015); Härle et al. (2015); Achi \& Sleilati (2016) and Danjuma et al. (2016). In addition, the results of this research also reject research conducted by Raj \& Sindhu (2013); Addo et al. (2018); Khandani et al. (2010); Idris \& Nayan (2016); Ssekiziyivu et al. (2018); Limakrisna (2018); Kristian \& Panjaitan (2014), and Keisidou et al. (2013); Mumbi \& Omagwa (2017) and Asante (2015). 
In carrying out its duties, AAO is also responsible for the survival of the debtor's credit journey. All activities undertaken to reduce credit risk are centered on the debtor, because through the debtor the quality and health of the bank's health can be maintained. Although it has been equipped with the knowledge gained from training, it is always equipped with facilities and infrastructure for credit monitoring, but still all that is returned to the skill of an AAO in safeguarding the debtor. Monitoring is the key to success in the credit process, because almost $70 \%$ is a credit monitoring process. In monitoring the debtor, an AAO must be able to know the problems faced by the debtor in the first opportunity so that he can take precautions as quickly as possible. In addition, AAO must also be able to become a mentor and become a business partner of the debtor in running its business, especially in financial matters (financial advisors).

But in reality, the monitoring process is not carried out properly and periodically. Based on the interview results, AAO has very rarely met directly and face to face due to additional activities (other than chasing disbursement targets of course). Being a committee for an event that should not be an AAO task is one of the causes. In addition, the obligation to seek additional funding (funding) also drains AAO time and energy. This additional activity also resulted in AAO having to think hard to be able to make it happen. Funding officer (FO) releases responsibility and submits all additional funding matters to AAO. Finally, not a few window dressing events were taken by AAO because they had no choice but to ask the debtor to transfer funds from a credit account to a savings account (Sohilauw, 2016).

These additional activities take up a lot of AAO time which ultimately reduces performance, especially in the monitoring process. Because of their busyness, the quantity of meetings with the debtor has dropped. Not a few AAO have rarely met face to face with the debtor, and are more using telephone and SMS to just "say hello". However, not a few AAOs are still routinely visiting debtors. However, that was, because both were busy, the quality of the meeting was not optimal. Thus, it is very normal for a debtor to feel that he or she is no longer being considered by the bank.

Other activities pursued by the bank are the development process through business capacity development training. In practice, the debtor is taught how to increase business capacity. Both in the field of marketing, bookkeeping, and so on. However, the continuity of meetings is an obstacle, because the speaker comes from the office and is usually referred to from Jakarta (head office), so that the average meeting with the debtor is only once. Banks are also not unaware of the lack, but they have no power because they determine everything from the head office. On the other hand, banks also do not want to cooperate with third parties (academics, professional institutions, consultants, etc.) in an effort to share the burden of fostering debtors, even if they (banks) want to work together there will certainly be many benefits received. This condition is very risky, especially credit risk because the debtor's monitoring and maintenance process as an early warning system does not run optimally.

To determine the position of the moderator variable in this study by comparing the original sample value for the relationship between Capital outflow monitoring management (COMM) / (Z) and loan performance $(\mathrm{Y})$ and the moderating effect (credit risk $(\mathrm{X})$ variable multiplied by the Capital outflow variable monitoring management (COMM) / (Z) on loan performance (Y) (Sugiono, 2004); (Ghozali, 2013).

If :

a. The original value of the sample effect of $\mathrm{Z}$ to $\mathrm{Y}$ is not accepted and the original value of the sample $(\mathrm{X} * \mathrm{Z}) \rightarrow \mathrm{Y}$ is accepted, then the moderator variable is called "pure moderator).

b. The original value of the sample effect of $Z$ to $Y$ is not accepted and the original value of the sample $\left(X^{*} \mathrm{Z}\right) \rightarrow \mathrm{Y}$ is not accepted, then the moderator variable is called "potential moderator", which means that the variable has the potential to be a moderating variable.

c. The original value of the sample influence of $\mathrm{Z}$ to $\mathrm{Y}$ is accepted and the original value of the sample $(\mathrm{X} * \mathrm{Z}) \rightarrow \mathrm{Y}$ is accepted, then the moderator variable is called "quasi moderator), which 
means a variable that moderates the relationship between the independent variable and the dependent variable which is also an independent variable .

d. The original value of the sample effect of $Z$ to $Y$ is accepted and the original value of the sample $(\mathrm{X} * \mathrm{Z}) \rightarrow \mathrm{Y}$ is not accepted, then the moderator variable is called the "moderator predictor", which means that this moderating variable only acts as an independent predictor variable in the relationship model formed.

By referring to the provisions written by Sugiono (2004) and Ghozali (2013) on the position of moderator variables, in table 14 it can be seen that the original value of the sample effect of the variable $\mathrm{Z}$ to $\mathrm{Y}$ is greater than the $\mathrm{P}$-value $(0.455>0.000)$, and the original value until variable $(\mathrm{X}$ * $\mathrm{Z})$ against variable $\mathrm{Y}$ is lower than $\mathrm{P}$-value $(0.114<0.332)$, so it can be concluded that the position of the moderator variable in this study is the Predictor Moderator (independent).

Table 6. R-Square Testing Results

\begin{tabular}{|l|c|}
\hline \multicolumn{1}{|c|}{ Variable Dependent } & R-Square \\
\hline Loan Performance & 0.622 \\
\hline
\end{tabular}

Source: Data processed (2018)

The value of R-square Loan Performance variable according to table 15 is 0.622 or $62.2 \%$. This can indicate that Loan Performance variable diversity can be explained by $62.2 \%$ Credit Risk and Capital Outflow Monitoring Management (COMM) variables, or in other words the contribution of Credit Risk and Capital Outflow Monitoring Management (COMM) variables to Loan Performance is $62.2 \%$, while the remaining $37.8 \%$ is the contribution of other variables not addressed in this study.

\section{Conclusion}

This paper discusses the moderating effect of Capital outflow monitoring management (COMM) variable on the relationship between credit risk and loan performance variables. The results obtained prove that credit risk has a positive effect on loan performance. The next hypothesis is the relationship between Capital outflow monitoring management (COMM) moderation on the relationship between the variables of credit risk and loan performance does not affect, and the Capital outflow monitoring management (COMM) variable acts as a moderator (independent) Predictor. There is no form of moderation between credit risk, loan performance and Capital outflow monitoring management (COMM is due to the lack of customer development from the bank. Due to other activities provided, AAO's main task in developing debtors is neglected. In addition, the bank also rarely provide training to increase business capacity to debtors.

1. Theoretically, this study supports the concepts and theories that already existed before. That is, the concept and the more mature so that the accountability and use for research is better.

2. Empirically, because there are rejected hypotheses (hypothesis 2), the use of concepts and theories is also very dependent on the location and time of the study. The real conditions that occur in the field make the respondents answer what they are without being hidden. As previously explained, over loading of AAO jobs is the main reason why debtor monitoring is not optimal. In addition, the unwillingness of the banks to cooperate with third parties in fostering debtors is another reason why debtor monitoring is not optimal. Thus, the overall results of the research are in accordance with the real conditions that occur in the field

3. For managerial implications, the results of this study must be a serious concern for banks because it is very risky for loans. Banks will become unhealthy if credit quality deteriorates.

This study only took a sample of AAO BRI for the 2009 BRI Regional Office. For better results, further research could involve AAO samples from private banks.

Based on the conclusions, implications and limitations of the research, the suggestions that the writer can put forward are as follows : 
1. The function of AAO must be separated into a Sales Officer (the task is to find new customers), Credit Analyst / loan officer (the part in charge of analyzing credit), Relationship Officer (debtor maintenance department), NPL Officer (in charge of managing non-performing loans). Separation of this function is solely for the sake of independence of duties and responsibilities. Marketing will be more focused because the tasks are in their respective fields.

2. AAO should not be given additional assignments that have nothing to do with their main task, such as having to find funding (funding) which is actually already a funding officer, because they have to focus on the credit process. It was feared that if AAO had to raise funds, cheating such as window dressing had the potential to occur and their time would be wasted, reducing the opportunity to process credit.

3. The Bank must be willing to cooperate with third parties (academics, professional consultants) in fostering customers, so that there is synergy with the surrounding environment. If you expect it from internal parties, then the coaching process will not be optimal.

4. Conceptually, the existence of a rejected hypothesis can be used as the starting material for further research and find the cause.

The concept of Capital outflow monitoring management (COMM) must be dissected and used in other studies to examine the level of accuracy and maturity of the concept. It is interesting to see this concept being tested on respondents from other banks (especially the private sector) who are very concerned about their debtors in their daily lives. In my opinion, the area that can be explored in future research is how to monitor and mentor existing debtors from AAO perspectives and third parties (academics and professional consultants), so that the GAP between credit risk and loan performance can be reduced or even eliminated. Other areas that can be explored are credit card debtors, because the level of debtor non-performing loans is quite high. In addition, the submission process until the approval of the credit card application is easier than other loan products.

\section{References}

Abor, J. (2007). Debt policy and performance of SMEs Evidence from Ghanaian and South African firms.pdf. The Journal of Risk Finance, 8(4), 364-379. https://doi.org/10.1108/15265940710777315

Achi, S. El, \& Sleilati, E. (2016). The effect of coaching on employee performance in the human resource management field: the case of the Lebanese banking sector. International Journal of Trade and Global Markets, 9(2), 137. https://doi.org/10.1504/IJTGM.2016.076321

Addae-Korankye, A. (2014). Causes and Control of Loan Default / Delinquency in Microfinance Institutions in Ghana. American International Journal of Contemporary Research, 4(12), 3645.

Addo, P., Guegan, D., \& Hassani, B. (2018). Credit Risk Analysis Using Machine and Deep Learning Models. Risks, 6(2), 38. https://doi.org/10.3390/risks6020038

Adebisi, J. F., \& Benjamin, O. M. (2015). The Impact of Non-Performing Loans on Firm Profitability: A Focus on the Nigerian Banking Industry. American Research Journal of Business and Management, 1(4), 1-7. https://doi.org/ISSN: 2379-1047

Adhikary, B. K. (2006). Nonperforming Loans in the Banking Sector of Bangladesh : Realities and Challenges. Bangladesh Institute of Bank Management, 75-95.

Afriyie, H. O., \& Akotey, J. O. (2013). Credit Risk Management and Profitability of Rural Banks in the Brong Ahafo Region of Ghana. European Journal of Business and Management, 5(24), 24 34. https://doi.org/ISSN : 2222-1905

Agier, I. (2012). The role of credit officers in the performance of micro loans. Evidence from Brazil. Economics of Transition, 20(2), 271-297. https://doi.org/10.1111/j.1468-0351.2012.00434.x

Agrawal, M. L. (2004). Customer relationship management (crm) \& corporate renaissance. Journal of Service Research, 3(2), 68-73.

Ahmed, S. F., \& Malik, Q. A. (2015). Credit Risk Management and Loan Performance : Empirical 
Investigation of Micro Finance Banks of Pakistan. International Journal of Economics and Financial Issues, 5(2), 574-579.

Ahn, S., \& Choi, W. (2009). The role of bank monitoring in corporate governance: Evidence from borrowers' earnings management behavior. Journal of Banking and Finance, 33(2), 425-434. https://doi.org/10.1016/j.jbankfin.2008.08.013

Akinlo, O., \& Emmanuel, M. (2014). Determinants of Non-Performing Loans in Nigeria. Accounting \& Taxation, 6(2), 21-28. https://doi.org/ISSN: 2157-0175

Akter, R., \& Roy, J. K. (2017). The Impacts of Non-Performing Loan on Profitability: An Empirical Study on Banking Sector of Dhaka Stock Exchange. International Journal of Economics and Finance, 9(3), 126. https://doi.org/10.5539/ijef.v9n3p126

Al-Mzary, M. M. M., Al-rifai, A. (Mohammad H. D. ., \& Momany, M. O. E. A.-. (2015). Training and its Impact on the Performance of Employees at Jordanian Universities from the Perspective of Employees: The Case of Yarmouk University. Journal of Education and Practice, 6(32), 128 140.

Aliija, R., \& Muhangi, B. W. (2017). The Effect of Loan Appraisal Process Management on Credit Performance in Microfinance Institutions (MFIs): A Case of MFIs in Uganda. International Journal of Science and Research, 6(4). https://doi.org/10.21275/ART20172815

Alshatti, A. sulieman. (2015). The effect of credit risk management on financial performance of the Jordanian commercial bank. Investment Management and Financial Innovations, 12(1), 338345. https://doi.org/10.5897/AJBM2013.7171

Anitha, R., \& Kumar, M. A. (2016). A STUDY ON THE IMPACT OF TRAINING ON EMPLOYEE PERFORMANCE IN PRIVATE INSURANCE SECTOR, COIMBATORE DISTRICT. International Journal of Management Research \& Review, 6(8), 1079-1080.

Asante, Y. A. (2015). Assessing Credit Management Practices in Savings \& Loans Companies: A Case Study of First Allied Savings \& Loans Ltd, Ksi. Kwame Nkrumah University of Science and Technology. Retrieved from http://ir.knust.edu.gh/bitstream/123456789/8499/1/Assessing Credit Management Practices in Savings project .pdf

Asfaw, A. S., Bogale, H. N., \& Teame, T. T. (2016). Factors Affecting Non-Performing Loans : Case Study on Development Bank of Ethiopia. International Journal of Scientific and Research Publications, 6(5), 656-670.

Auronen, L. (2003). Asymmetric information: theory and applications. Seminar of Strategy and International Business at ..., 1-35. Retrieved from http://citeseerx.ist.psu.edu/viewdoc/download?doi=10.1.1.198.9252\&rep=rep1\&type=pdf

Bace, E. (2016). Bank profitability: Liquidity, capital and asset quality. Journal of Risk Management in Financial Institutions, 8887(4), 327-331.

Bagh, T., Razzaq, S., Azad, T., Liaqat, I., \& Khan, M. A. (2017). The Causative Impact of Liquidity Management on Profitability of Banks in Pakistan: An Empirical Investigation. International Journal of Academic Research in Economics and Management Sciences, 6(3). https://doi.org/10.6007/IJAREMS/v6-i3/3151

Baiden, J. E. (2011). The 5 C's of Credit in the Lending Industry. Ssrn. https://doi.org/10.2139/ssrn.1872804

Baklouti, I., \& Baccar, A. (2013). Evaluating the predictive accuracy of microloan officers' subjective judgment. International Journal of Research Studies in Management, 2(2), 21-34. Retrieved from http://www.consortiacademia.org/index.php/ijrsm/article/view/343

Balasubramaniam, C. . (2013). Non-Performing Assets and Profitability of Commercial Banks in India: Assessment and Emerging Issues. Abhinav NATIONAL MONTHLY REFEREED JOURNAL OF REASEARCH IN COMMERCE \& MANAGEMENT, 1(7).

Balla, E., \& Rose, M. J. (2011). Loan Loss Reserves, Accounting Constraints, and Bank Ownership Structure (No. 11-09). Ssrn. https://doi.org/10.2139/ssrn.2190609

Bank Indonesia. (1997). SEJARAH BANK INDONESIA: PERBANKAN Periode 1983-1997. 
Jakarta: Bank Indonesia.

Bank Indonesia. SE BI nomor 7/3/DPNP tanggal 31 Januari 2005 Perihal Penilaian Kualitas Aktiva Bank Umum. (2005). Indonesia.

Bank Indonesia. Peraturan Bank Indonesia Nomor: 13/1/PBI/2011 Tentang Penilaian Tingkat Kesehatan Bank Umum, Peraturan Bank Indonesia § (2011).

Bank Indonesia. PERATURAN BANK INDONESIA NOMOR 14/ 15 /PBI/2012 TENTANG PENILAIAN KUALITAS ASET BANK UMUM, Pub. L. No. NOMOR 14/ 15 /PBI/2012 (2012). Indonesia.

Barney, J. B. (1991). Firm Resources and Sustained Competitive Advantage. Journal of Management, 17(1), 99-120.

Barney, J. B., \& Hesterly, W. S. (2015). Strategic Management and Competitive Advantage: Concepts and Cases (Global Edi). Edinburg: Pearson Education Limited 2015.

Basel Committee. (2000). Principles for the management of credit risk. Bank for International Settlements.

Bezzina, F., Grima, S., \& Mamo, J. (2014). Risk management practices adopted by financial firms in Malta. Managerial Finance, 40(6), 587-612. https://doi.org/10.1108/MF-08-2013-0209

Bhattarai, Y. R. (2016). Effect of Credit Risk on the Performance of Nepalese Commercial Banks. NRB Economic Review, 4(1), 81-87. https://doi.org/10.1007/s13398-014-0173-7.2

Bozeman, B., \& Feeney, M. K. (2007). Toward a Useful Theory and Critique. Administration and Society, 39(6), 719-740. https://doi.org/10.1177/0095399707304119

Cerqueiro, G., Ongena, S., \& Roszbach, K. (2014). Collateralization , Bank Loan Rates , and Monitoring. Journal of Finance, 71(3), 1-49. https://doi.org/https://doi.org/10.1111/jofi.12214

Chang, Y. H., \& Chen, F. Y. (2007). Relational benefits, switching barriers and loyalty: A study of airline customers in Taiwan. Journal of Air Transport Management, 13(2), 104-109. https://doi.org/10.1016/j.jairtraman.2006.10.001

Chege, L. M., \& Bichanga, J. (2017). Non-Performing Loans and Financial Performance of Banks : An Empirical Study of Commercial Banks in Kenya. International Journal of Management and Commerce Innovations, 4(2), 909-916.

Chimkono, E. E., \& Muturi, W. (2016). Effect on non-performing loans and other factors on performance of commercial banks in Malawi. International Journal of Economics, Commerce and Management, IV(2), 549-563. https://doi.org/ISSN : 2348-0386

Coleman, A. D. F., Esho, N., \& Sharpe, I. G. (2006). Does bank monitoring influence loan contract terms? Journal of Financial Services Research, 30(2), 177-198. https://doi.org/10.1007/s10693-006-0017-5

D'Hulster, K., Letelier, R., \& Valeria, S.-G. (2014). LOAN CLASSIFICATION AND PROVISIONING: CURRENT PRACTICES IN 26 COUNTRIES. FINANCIAL SECTOR ADVISORY CENTRE.

Danjuma, I., Kola, I. A., Magaji, B. Y., \& Kumshe, H. M. (2016). Credit Risk Management and Customer Satisfaction in Tier-one Deposits Money Banks: Evidence from Nigeria. International Journal of Economics and Financial Issues, 6(2010), 225-230. Retrieved from http://www.econjournals.com/index.php/ijefi/article/view/2634

Dehlen, T., Zellweger, T., Kammerlander, N., \& Halter, F. (2014). The role of information asymmetry in the choice of entrepreneurial exit routes. Journal of Business Venturing, 29(2), 193-209. https://doi.org/10.1016/j.jbusvent.2012.10.001

DeYoung, R. (2017). How Relationships Can Reduce Risk in Small Business Lending. European Economy, Banks, Reg(Haltiwanger 2014), 4-9.

Diamond, D. (1984). Financial intermediation and delegated monitoring. Review of Economic Studies, 51(3), 393-414. https://doi.org/10.2307/2297430

Dung, N. A. (2014). Non-Performing Loan.

Embaye, S. S., Zahara, C. F., \& Abderaman, T. (2017). Impact of Credit Risk Management on 
Financial Performance of Commercial Banks-Evidence from Eritrea. Research Journal of Finance and Accounting, 8(19), 70-76. Retrieved from http://www.iiste.org/Journals/index.php/RJFA/article/view/39486

Eniola, A. A., \& Entebang, H. (2015). Government Policy and Performance of Small and Medium Business Management. International Journal of Academic Research in Business and Social Sciences, 5(2), 237-248. https://doi.org/10.6007/IJARBSS/v5-i2/1481

Erdoğan, S. (2014). Bank Lending Criteria and Relationship Lending. Journal of Advanced Management Science, 2(3), 220-227. https://doi.org/10.12720/joams.2.3.220-227

Etale, L. M., Ayunku, P. E., \& Etale, E. L. M. (2016). The Impact of Non-Performing Loans and Bank Performance in Nigeria. International Journal of Humanities and Social Science Invention, 5(4), 1-5. https://doi.org/ISSN : 2319-7714

Fun Ho, C. S., \& Yusoff, N. I. (2009). A Preliminary Study on Credit Risk Management Strate- gies of Selected Financial Institutions in Malaysia. A Preliminary Study on Credit Risk Management Strategies Jurnal Pengurusan, 28, 45-65.

Gakure, R. ., Ngugi, J., Ndwiga, P., \& Waithaka, S. (2012). EFFECT OF CREDIT RISK MANAGEMENT TECHNIQUES ON THE PERFORMANCE OF UNSECURED BANK LOANS EMPLOYED COMMERCIAL BANKS IN KENYA. International Journal of Business and Social Research, 2(4), 221-236.

García, F., Giménez, V., \& Guijarro, F. (2012). Credit risk management: A multicriteria approach to assess creditworthiness. Mathematical and Computer Modelling, 57(7-8), 2009-2015. https://doi.org/10.1016/j.mcm.2012.03.005

Ghozali, I. (2013). Aplikasi Analisis Multivariate Dengan Program IBM SPSS 21 Update PLS Regresi (7th ed.). Semarang: Badan Penerbit Universitas Diponegoro. Retrieved from https://www.researchgate.net/publication/289671928_Aplikasi_Analisis_Multivariate_Denga n_Program_IBM_SPSS_21_Update_PLS_Regresi

Grinis, I. (2015). Credit Risk Spillovers, Systemic Importance and Vulnerability in Financial Networks Credit Risk Spillovers, Systemic Importance and Vulnerability in Financial Networks (SRC Discussion Paper No. 27). London.

Gunadi, I., \& Taruna, A. A. (2015). THE IMPACT OF BANK LIQUIDITY RISK ON THE CHANNELING OF LOANS (No. 11).

Güneş, N. (2015). DETERMINANTS OF BANK PROFITABILITY: 2002-2012 PERIOD OF TURKISH DEPOSIT BANKS ON A REVIEW. The Journal of Faculty of Economics and Administrative Sciences, 20(3), 265-282.

Gustafson, M., Ivanov, I., \& Meisenzahl, R. R. (2016). Bank Monitoring: Evidence from Syndicated Loans. Ssrn, (August). https://doi.org/10.2139/ssrn.2831455

Gweyi, M. O. (2013). Credit Risk Mitigation Strategies Adopted By Commercial Banks in Kenya. International Journal of Business and Social Science, 4(6).

Haneef, S., Riaz, T., Ramzan, M., Rana, M. A., Assistant, H. M. I., \& Karim, Y. (2012). Impact of Risk Management on Non-Performing Loans and Profitability of Banking Sector of Pakistan. International Journal of Business and Social Science, 3(7), 307-315.

Härle, P., Havas, A., Kremer, A., Rona, D., \& Samandari, H. (2015). The future of bank risk management (Global Risk Practice). McKinsey Working Papers on Risk. Retrieved from http://www.mckinsey.com/business-functions/risk/our-insights/the-future-of-bank-riskmanagement

Hosna, A., Manzura, B., \& Juanjuan, S. (2009). Credit Risk Management and Profitability. University of Gothenburg.

Idris, I. T., \& Nayan, S. (2016). The moderating role of Loan monitoring on the relationship between macroeconomic variables and non-performing loans in ASEAN countries. International Journal of Economics and Financial Issues, 6(2), 402-408.

Ikatan Bankir Indonesia. (2015). Manajemen Risiko 1 (Vol. 1). 
investopedia.com. (2010). Financial Intermediary. Retrieved October 6, 2018, from https://www.investopedia.com/terms/f/financialintermediary.asp

Jusuf, J. (2008). Panduan Dasar untuk Account Officer (Edisi Ketiga) (3rd Editio). Jogjakarta: UPP STIM YKPN.

Kalu, E. O., Shieler, B., \& Amu, C. U. (2018). Credit Risk Management and Financial Performance of Microfinance Institutions in Kampala, Uganda. Independent Journal of Management \& Production, 9(1), 153. https://doi.org/10.14807/ijmp.v9i1.658

Kargi, H. S. (2011). Credit risk and the performance of Nigerian banks. Acme Journal of Accounting Economics and Finance. Ahmadu Bello University. Retrieved from http://www.acmejournals.com/Journals/Social-Sciences/AJAEF/archive.html

Kasmir. (2015). Bank dan Lembaga Keuangan Lainnya. (Kasmir, Ed.) (revised ed). Jakarta: PT. RajaGrafindo Persada.

Katerega, Y. N., Ngoma, M., Masaba, A. K., Nangoli, S., \& Waswa, Y. (2015). Financing decision : A vital key to explaining small and medium enterprises ( SMEs ) financial performance. Journal of Economics and International Business Management, Vol. 3(2)(December), 51-58.

Keisidou, E., Sarigiannidis, L., Maditinos, D. I., \& Thalassinos, E. I. (2013). Customer satisfaction, loyalty and financial performance: A holistic approach of the Greek banking sector. International Journal of Bank Marketing, 31(4), 259-288. https://doi.org/10.1108/IJBM-112012-0114

Kementrian Tenaga Kerja. Standar Kompetensi Kerja Nasional Indonesia (SKKNI) (2017).

Khandani, A. E., Kim, A. J., \& Lo, A. W. (2010). Consumer credit-risk models via machine-learning algorithms. Journal of Banking and Finance, 34(11), 2767-2787. https://doi.org/10.1016/j.jbankfin.2010.06.001

Khemraj, T., \& Pasha, S. (2009). The determinants of non-performing loans: an econometric case study of Guyana. Asian Economic and Financial Review (Vol. 5). https://doi.org/10.18488/journal.aefr/2015.5.6/102.6.868.882

Kibor, A. M., Ngahu, S. T., \& Kwasira, J. (2015). Influence of Credit Risk Management Practices on Loan Performance of Microfinance Institutions in Baringo County. International Journal of Economics, Commerce and Management, 3(10), 2260-2267. https://doi.org/10.5281/zenodo.572281

Kimotho, D. N., \& Gekara, M. (2016). Effects of Credit Risk Management Practices on Financial Performance of Commercial banks in Kenya. International Journal of Business International Journal of Economics \& Finance ISSN International Journal of Business Social Sciences and Education/ Ijbsse. Org International Journal of Business, 2(3), 116-16.

Kingu, P. S., Macha, D. S., \& Gwahula, D. R. (2018). Impact of Non-Performing Loans on Bank's Profitability: Empirical Evidence from Commercial Banks in Tanzania. International Journal of Scientific Research and Management, 6(01), 71-78. https://doi.org/10.18535/ijsrm/v6i1.em11

Kiplimo, K. S., \& Kalio, A. M. (2014). Influence of Credit Risk Management Practices on Loan Performance of Microfinance Institutions in Baringo County. International Journal of Science and Research (IJSR), 3(10), 2260-2267. https://doi.org/10.5281/zenodo.572281

Kipyego, D. K., \& Wandera, M. (2013). Effects of Credit Information Sharing on Nonperforming Loans : the Case of Kenya Commercial Bank Kenya. European Scientific Journal, 9(13), 168193.

Kithinji, A. (2010). Credit Risk Management and Profitability of Commercial Banks in Kenya. International Journal of Business, Humanities and Technology, 3(2), 27-30.

Klein, M. A. (1971). A Theory of the Banking Firm. Journal of Money, Credit and Banking, 3(2), 205-218. https://doi.org/10.2307/1991279

Klieštik, T., \& Cúg, J. (2015). Comparison of Selected Models of Credit Risk. Procedia Economics and Finance, 23, 356-361. https://doi.org/10.1016/S2212-5671(15)00452-9 
Koju, L., Koju, R., \& Wang, S. (2018). Does Banking Management Affect Credit Risk? Evidence from the Indian Banking System. International Journal of Financial Studies, 6(3), 67. https://doi.org/10.3390/ijfs6030067

Kolapo, T. F., Ayeni, R. K., \& Oke, M. O. (2012). Credit risk and commercial banks' performance in Nigeria: A panel model approach. Australian Journal of Business and Management Research, 2(02), 31-38.

Krasnikov, A., Jayachandran, S., \& Kumar, V. (2009). The Impact of Customer Implementation on Cost and Profit Efficiencies : Evidence from the U . S . Commercial Banking Industry. Journal of Marketing, 73(November), 61-76. https://doi.org/10.1509/jmkg.73.6.61

Kristian, F. A. B., \& Panjaitan, H. (2014). Analysis of Customer Loyalty through Total Quality Service, Customer Relationship Management, and Customer Satisfaction. International Journal of Evaluation and Research in Education, 3(3), 142-151. Retrieved from https://doaj.org/article/0465bd7a497640f8b82caa11cf99602a

Lagat, F. K., Mugo, R., \& Otuya, R. (2013). Effect of Credit Risk Management Practices on Lending Portfolio Among Savings and Credit Cooperatives in Kenya. European Journal of Business and Management, 5(19), 2222-2839.

Lalon, R. M. (2015). Credit Risk Management (CRM) Practices in Commercial Banks of Bangladesh: "A Study on Basic Bank Ltd." International Journal of Economics, Finance and Management Sciences, 3(2), 78. https://doi.org/10.11648/j.ijefm.20150302.12

Lata, R. S. (2015). Non-Performing Loan and Profitability: The Case of State Owned Commercial Banks in Bangladesh. World Review of Business Research Vol., 5(3), 171-182.

Latan, H., \& Ghozali, I. (2015). Partial Least Squares: Concepts, Techniques and Applications using SmartPLS 3 (2nd Editio). Semarang: Diponegoro University Press.

Lebbe, A., Rauf, A., \& Mulafara, A. H. (2016). Influence of Credit Risk Management on Loan Performance: Special Reference from Commercial Banks of Ampara District in Sri Lanka. International Journal of Advances in Management and Economics, 5(4), 30-35. https://doi.org/10.5281/zenodo.572281

Li, F., \& Zou, Y. (2014). The Impact of Credit Risk Management on Profitability of Commercial Banks: A Study of Europe. Umea Universitet.

Liang, L. W., Huang, B. Y., Liao, C. F., \& Gao, Y. T. (2017). The impact of SMEs' lending and credit guarantee on bank efficiency in South Korea. Review of Development Finance, 7(2), 134-141. https://doi.org/10.1016/j.rdf.2017.04.003

Limakrisna, N. (2018). Building Customer Loyalty in Banking Industy. Modern Management Forum, 2(1), 1-6. https://doi.org/10.18686/mmf.v2i1.1057

Lodico, M. G., Spaulding, D. T., \& Voegtle, K. H. (2006). Methods in Educational Research: From Theory to Practice. https://doi.org/10.1037/a0007948

Maina, J. N., Kinyariro, D. K., \& Harrison, M. M. (2016). Influence of Credit Risk Management Practices on Loan Delinquency in Savings and Credit Cooperative Societies in Meru County, Kenya. International Journal of Economics, Commerce and Management, IV(2), 763-773.

Maluni, O. M. (2011). The Relationship Between Credit Risk Management Practices and The Level of Non-Performing Loans for Commercial Banks in Kenya. University of Nairobi.

Matu, J. Ben. (2008). Attracting Microfinance Investment Funds: Promoting Microfinance Growth through Increased Investments in Kenya (No. 12084). Duke.

McLaughlin, C. (2010). Mentoring: What is it? How do we do it and how do we get more of it? Health Services Research, 45(3), 871-884. https://doi.org/10.1111/j.1475-6773.2010.01090.x

Mcqueen, R. (2001). the Corporate Image - the Regulation of Annual Reports. Macquarie Law Journal, 1(1), 93-128.

Mester, L. J., Nakamura, L. I., \& Renault, M. (2007). Transactions accounts and loan monitoring. Review of Financial Studies, 20(3), 528-556. https://doi.org/10.1093/rfs/hhl018

Ministry of Finance. UNDANG-UNDANG REPUBLIK INDONESIA NOMOR 10 TAHUN 1998 
(1998).

Moed, B. R. (2012). Mentoring: The role of a mentor and finding one. Journal of Orthopaedic Trauma, 26(9 SUPPL.), 23-24. https://doi.org/10.1097/BOT.0b013e3182642172

Mohamad, S. H., Othman, N. A., Jabar, J., \& Majid, I. A. (2014). Customer Relationship Management Practices: The Impact on Organizational Performance in SMEs of Food Manufacturing Industry. European Journal of Business and ManagementOnline), 6(13), 2222-2839.

Morris, C. S., \& Sellon, G. H. (1995). Bank lending and Monetary Policy: Evidence on a Credit Channel. Federal Reserve Bank of Kansas City Economic Review, 2nd Quarte, 59-75. Retrieved

from http://citeseerx.ist.psu.edu/viewdoc/download?doi=10.1.1.160.6525\&rep=rep1\&type=pdf

Moti, H., Masinde, J., Mugenda, N., \& Sindani, M. (2012). Effectiveness of Credit Management System on Loan Performance: Empirical Evidence from Micro Finance Sector in Kenya. International Journal of Business, Humanities and Technology, 2(6), 99-108.

Mugwe, M. W., \& Oliweny, T. (2013). The Effect of Credit Information Sharing on The Performance of Commercial Banks in Kenya. International Journal of Business and Commerce, 5(3), 41-63. https://doi.org/10.1007/s13398-014-0173-7.2

Muhamet, A., \& Arbana, S. (2016). The Effect of Credit Risk Management on Banks' Profitability in Kosovo. European Journal of Economic Studies, 18(4), 492-516. https://doi.org/10.13187/es.2016.18.492

Mumbi, W. M., \& Omagwa, J. (2017). Credit risk management and financial performance of selected commercial banks in Kenya. IOSR Journal of Business Management, 19(11), 92-98. https://doi.org/10.9790/487X-1911079298

Murigi, D. ., \& Thuo, A. (2018). CREDIT RISK MANAGEMENT AND LOAN PERFORMANCE IN MICROFINANCE BANKS IN KENYA. International Journal of Economics, Commerce and Management, VI(4), 623-643.

Mwinlaaru, P. Y., Ofori, I. K., Adiyiah, K. A., \& Idun, A. A.-A. (2016). Non-Performing Loans and Universal Bank's Profitabilit (No. 82902). University of Cape Coast.

Nguyen, L. (2016). Credit risk control for loan products in commercial banks. Case: Bank for Investment and Development of Vietnam. Haaga-Helia University. Retrieved from http://www.theseus.fi/bitstream/handle/10024/124820/Credit+risk+control+for+loan+product $\mathrm{s}+$ in + commercial+banks. +Case+BIDV.pdf;jsessionid=07BCA9DB6C88B8B78126A3301CC 8246A? sequence $=1$

Nguyen, T. H., Sherif, J. S., \& Newby, M. (2007). Strategies for successful CRM implementation. Information Management \& Computer Security, 15(2), 102-115. https://doi.org/10.1108/09685220710748001

Nikolaidou, E., \& Vogiazas, S. D. (2014). Credit Risk Determinants for the Bulgarian Banking System. International Advances in Economic Research, 20(1), 87-102. https://doi.org/10.1007/s1 1294-013-9444-x

Njeru, M., Mohammed, S., \& Wachira, A. (2016). Effects of Credit Risk Management on Loan Repayment Performance of Commercial Banks in Kenya. International Journal of Recent Engineering Research and Development (IJRERD), 1(6), 9-14.

Noman, A. H., Pervin, S., Chowdhury, M. M., \& Banna, H. (2015). The Effect of Credit Risk on the Banking Profitability: A Case on Bangladesh. Global Journal of Management and Business Research: C Finance, 15(3), 41-48.

Noor, C. M. (2015). Panduan Account Officer Bank Handal Dan Tangguh (Seri Manaj). Bandung: Quantum Expert Bandung.

Nsiah, R. (2017). AN EXAMINATION OF THE CREDIT MANAGEMENT PRACTICES OF RURAL BANKS: A CASE STUDY OF ASOKORE RURAL BANK LIMITED. Ssrn, (November). https://doi.org/10.2139/ssrn.2494259

Nyarko-baasi, M. (2018). Effects of Non-Performing Loans on the Profitability of Commercial Banks 
- A Study of Some Selected Banks on the Ghana Stock Exchange. Global Journal of Management and Business Research: C Finance, 18(2).

Nyasaka, F. O. (2017). THE RELATIONSHIP BETWEEN CREDIT RISK MANAGEMENT PRACTICES AND NON-PERFORMING LOANS IN KENYAN COMMERCIAL BANKS: A CASE STUDY OF KCB GROUP LIMITED. UNITED STATES INTERNATIONAL UNIVERSITY - AFRICA.

Onuko, L. K., Munir Muganda, \& Musiega, D. (2015). Effect of Credit Risk Management on Loan Portfolio Quality of Tier One Commercial Banks in Kenya. International Journal of Business and Management Invention, 4(7), 46-53. Retrieved from www.ijbmi.org46\%7C

Onyango, J. W., \& Wanyoike, D. M. (2014). Effects of Training on Employee Performance: a Survey of Health Workers in Siaya County, Kenya. European Journal of Material Sciences, 1(1), $11-$ 15. https://doi.org/10.1017/CBO9781107415324.004

Osei-Nyarko, G. (2015). Credit Appraisal Process and Repayment of Loan At Gn Bank. Kwame Nkrumah University.

Otieno, S., Nyagol, M., \& Onditi, A. (2016). Relationship between Credit risk management and financial performance: empirical evidence from microfinance banks in Kenya. Research Journal of Finance and Accounting, 7(6), 115-142.

Owino, M. O. (2014). THE EFFECT OF THE LENDING POLICIES ON THE LEVELS OF NONPERFORMING LOANS (NPLs) OF COMMERCIAL BANKS IN KENYA. University of nairobi.

Ozili, P. K. (2017). Non-performing loans and Financial Development: New Evidence (No. 80231). Management. United Kingdom. https://doi.org/10.1111/j.1574-0862.2010.00507.x/abstract

Payne, A., \& Frow, P. (2005). A Strategic Framework for Customer. Journal of Marketing, 69, 167176. https://doi.org/10.1509/jmkg.2005.69.4.167

Peteraf, M. A. (1993). The Cornerstones of Competitive Advantage: A Resource-Based View. Strategic Management Journal, 14(3), 179-191. Retrieved from http://www.jstor.org/stable/2486921

Pottow, J. A. E., Lawless, R. M., Littwin, A. K., Porter., K. M., \& Thorne, D. K. (2008). Did bankruptcy reform fail? An empirical study of consumer debtors. American Bankruptcy Law Journal, 82(3), 349-406.

Prado, L. S. do, \& Martinelli, D. P. (2018). Analysis of negotiation strategies between buyers and sellers: an applied study on crop protection products distribution. RAUSP Management Journal, 53(2), 225-240. https://doi.org/10.1016/j.rauspm.2018.01.001

Psillaki, M., Tsolas, I. E., \& Margaritis, D. (2010). Evaluation of credit risk based on firm performance. European Journal of Operational Research, 201(3), 873-881. https://doi.org/10.1016/j.ejor.2009.03.032

Raj, B., \& Sindhu. (2013). Managing Non-financial Risks : Business \& Growth. Journal of Indian Management, 10(4), 63-75.

Rodrigues, S. da S., \& Galdi, F. C. (2017). Investor relations and information asymmetry. Revista Contabilidade \& Finanças, 28(74), 297-312. https://doi.org/10.1590/1808-057x201703630

Ruziqa, A. (2013). The impact of credit and liquidity risk on bank financial performance: the case of Indonesian Conventional Bank with total asset above 10 trillion Rupiah. International Journal of Economic Policy in Emerging Economies, 6(2), 93. https://doi.org/10.1504/IJEPEE.2013.055791

Saba, I., Kouser, R., \& Azeem, M. (2012). Determinants of Non Performing Loans: Case of US Banking Sector. The Romanian Economic Journal, 15(January), 141-152.

Samırkaş, M. C., Evci, S., \& Ergün, B. (2014). DETERMINANTS OF PROFITABILITY IN THE TURKISH BANKING SECTOR. Kafkas University Journal of Economics and Administrative Sciences Faculty, 5(8), 117-134.

Sampagnaro, G., Meles, A., \& Verdoliva, V. (2015). Monitoring in small business lending: How to 
observe the unobservable. Journal of Financial Research, 38(4), 495-510. https://doi.org/10.1111/jfir.12082

Samreen, A., Zaidi, F. B., \& Sarwar, A. (2013). Design and development of credit scoring model for the commercial banks of Pakistan: forecasting creditworthiness of individual borrowers. International Journal of Business and Social Science, 2(5), 1-26.

Scholtens, B., \& van Wensveen, D. (2003). The Theory of Financial Intermediation: An Essay On What It Does (Not) Explain. SUERF - The European Money and Finance Forum, 1. Retrieved from http://hdl.handle.net/10419/163455\%0AStandard-Nutzungsbedingungen:

Schwarz, A. (2011). Measurement, Monitoring, and Forecasting of Consumer Credit Default Risk An Indicator Approach Based on Individual Payment Histories (No. 004).

Shem, J. M., \& Ngussa, B. M. (2017). Effect of Training on Employees' Performance: A Case of Institutions of Higher Learning in Arusha City, Tanzania. International Journal of Science and Research, 6(10). https://doi.org/10.21275/27101703

Sohilauw, M. I. S. (2016). Window Dressing Sebagai Manifestasi Ekonomi Kapitalis. Jurnal IImiah Bongaya,: 1907-5480, (Xix), : 114-128.

Spuchl'áková, E., Valašková, K., \& Adamko, P. (2015). The Credit Risk and its Measurement, Hedging and Monitoring. Procedia Economics and Finance, 24(July), 675-681. https://doi.org/10.1016/S2212-5671(15)00671-1

Srinivasan, B., \& Fox, I. (1993). Asset Specificity , Firm Heterogeneity and Capital Structure. Strategic Management Journal, 14(1), 3-16. Retrieved from http://www.jstor.org/stable/2486546 Accessed :

Ssekiziyivu, B., Bananuka, J., Nabeta, I. N., \& Tumwebaze, Z. (2018). Borrowers' characteristics, credit terms and loan repayment performance among clients of microfinance institutions (MFIs): Evidence from rural Uganda. Journal of Economics and International Finance, 10(1), 1-10. https://doi.org/10.5897/JEIF2017.0848

Sugiono. (2004). KONSEP, IDENTIFIKASI, ALAT ANALISIS DAN MASALAH PENGGUNAAN VARIABEL MODERATOR. JURNAL STUDI MANAJEMEN \& ORGANISASI, 1(2), 61-70. Retrieved from http://ejournal.undip.ac.id/index.php/smo

Svitek, I. M. (2011). Functions of Bank Capital. Biatec.

Taiwo, J., Ucheaga, E., Achugamonu, B., Adetiloye, K., Okoye, L., \& Agwu, M. . (2017). Credit Risk Management: Implications on Bank Performance and Lending Growth. Saudi Journal of Business and Management Studies, 2(5), 584-590. https://doi.org/10.21276/sjbms

The Basel Committe. (2006). Principles for the Management of Credit Risk. IFAS Extension, 1-33. Retrieved from http://edis.ifas.ufl.edu/pdffiles/HR/HR02200.pdf

Thisika, M. L., \& Jomo, W. M. (2017). EFFECTS OF CREDIT RISK MANAGEMENT ON LOAN PERFORMANCE IN KENYAN COMMERCIAL BANKS. International Journal of Economics, Commerce and Management, United Kingdom, 5(9), 13.

Veizi, Z., Mano, R., \& Koçiu, L. (2016). the Efect of Credit Risk on the Banking Profitability : a Case on Albania. International Journal of Economics, Commerce and Management, IV(7), 386-394.

Vinh, N. T. H. (2017). The Impact of Non-Performing Loans on Bank Profitability and Lending Behavior: Evidence from Vietnam. Jounal of Economic Development, 24(3), 27-44. https://doi.org/10.17015/ejbe.2015.016.04

Wachira, A. K. (2017). EFFECTS OF CREDIT RISK MANAGEMENT PRACTICES ON LOAN PERFORMANCE OF COMMERCIAL BANKS IN NYERI COUNTY, KENYA. European Journal of Economic and Financial Research, 2(2). https://doi.org/10.5281/zenodo.572281

Yimka, A. S., Agbatogun, T., Abimbola, C., \& Adekunle, O. (2015). Credit risk management and financial performance of selected commercial banks in Nigeria Alalade. Journal of Economic \& Financial Studies, 3(01), 01-09. https://doi.org/10.18533/jefs.v3i01.73

Zaini Abd Karim, M., Chan, S.-G., \& Hassan, S. (2010). Bank Efficiency and Non-Performing Loans: Evidence from Malaysia and Singapore. Prague Economic Papers, 19(2), 118-132. 
https://doi.org/10.18267/j.pep.367 